\title{
Linkages between soil carbon, soil fertility and nitrogen fixation in Acacia senegal plantations of varying age in Sudan
}

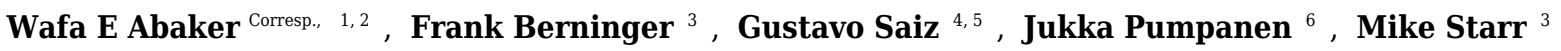 \\ ${ }^{1}$ Department of Forest Sciences, Viikki Tropical Resources Institute, University of Helsinki, Helsinki, Finland \\ 2 Faculty of Forestry, University of Khartoum, Khartoum, Sudan \\ 3 Department of Forest Sciences, University of Helsinki, Helsinki, Finland \\ 4 Department of Environmental Chemistry / Faculty of Sciences, Universidad Católica de la Santísima Concepción, Concepción, Chile \\ 5 Department of Life Sciences, Imperial College London, Ascot, United Kingdom \\ 6 Department of Environmental and Biological Sciences, University of Eastern Finland, Kuopio, Finland \\ Corresponding Author: Wafa E Abaker \\ Email address: wafa.abaker@helsinki.fi
}

Background . Over the last decades sub-Saharan Africa has experienced severe land degradation and food security challenges linked to loss of soil fertility and soil organic matter (SOM), recurrent drought and increasing population. Although primary production in drylands is strictly limited by water availability, nutrient deficiencies, particularly of $\mathrm{N}$ and $\mathrm{P}$, are also considered limiting factors for plant growth. It is known that SOM (often measured as soil organic carbon, SOC) is a key indicator of soil fertility, therefore,management practices that increase SOM contents, such as increasing tree cover, can be expected to improve soil fertility. The objectives of this study were to investigate the effect of Acacia senegal (Senegalia senegal) trees on soil nitrogen $(\mathrm{N})$, phosphorus $(\mathrm{P})$ and potassium $(\mathrm{K})$ in relation to SOC, the potentialof $A$. senegal for $\mathrm{N}_{2}$ fixation, and to identify possible $\mathrm{N}$ and $\mathrm{P}$ ecosystem limitations.

Methods. Soil nutrient (total N, P, K and available P and exchangeable K) concentrations and stocks were determined in the $0-10,10-20,20-30$ and $30-50 \mathrm{~cm}$ layers of $A$. senegal plantations of varying age (ranging from 7 to 24-years-old) and adjacentgrasslands (reference) at two sites in semi-arid areas of Sudan. At both sites,three plots were established in each grassland and plantation. The potential of $A$. senegal for $\mathrm{N}_{2}$ fixation in relation to plantations age was assessed using $\delta{ }^{15} \mathrm{~N}$ isotopic abundances and nutrient limitations assessed using C:N:P stoichiometry.

Results. Soil concentrations of all studied nutrients were relatively low but were significantly and directly correlated to SOC concentrations. SOC and nutrient concentrations were the highest in the topsoil (0-10 $\mathrm{cm}$ ) and increased with plantations age. Acacia foliage $\delta{ }^{15} \mathrm{~N}$ values were $>6 \%$ and varied little with plantations age. Soil C:N and C:P ratios did not differ between grassland and plantations and only 0-10 $\mathrm{cm}$ layer N:P ratios showed significant differences between grassland and plantations.

Discussion. The results indicated that soil fertility in the Sahel region is strongly related to SOM contents and therefore highlighting the importance of trees in the landscape. The higher mineral nutrient concentrations in the topsoil of the plantations may be an indication of "nutrient uplift" by the deeper roots. The high foliar $\delta{ }^{15} \mathrm{~N}$ values indicated that $\mathrm{N}_{2}$ fixation was not an important contributor to soil $\mathrm{N}$ contents in the plantations. The accretion of soil $\mathrm{N}$ cannot be explained by deposition but may be related to inputs of excreted $\mathrm{N}$ brought into the area annually by grazing and browsing animals. The soil $\mathrm{C}: \mathrm{N}: \mathrm{P}$ stoichiometry indicated that the plantations may be limited by $\mathrm{P}$ and the grasslands limited by $\mathrm{N}$. 
1 Linkages between soil carbon, soil fertility and nitrogen fixation in Acacia senegal

2 plantations of varying age in Sudan.

3

4 Wafa E Abaker 1,2,*, Frank Berninger³, Gustavo Saiz ${ }^{4,5}$, Jukka Pumpanen ${ }^{6}$, Mike Starr ${ }^{3}$

$6{ }^{1}$ Department of Forest Sciences, Viikki Tropical Resources Institute (VITRI), P.O. Box 27, FI-

700014 University of Helsinki, Helsinki, Finland

$8{ }^{2}$ Faculty of Forestry, University of Khartoum, 13314 Shambat, Sudan

$9{ }^{3}$ Department of Forest Sciences, P.O. Box 27, FI-00014 University of Helsinki, Helsinki,

10 Finland

$11{ }^{4}$ Department of Environmental Chemistry, Faculty of Sciences, Universidad Católica de la

12 Santísima Concepción, Concepción, Chile

$13{ }^{5}$ Department of Life Sciences, Imperial College London, Silwood Park Campus, Buckhurst

14 Road, Ascot, Berkshire SL5 7PY, UK

$15{ }^{6}$ Department of Environmental and Biological Sciences, University of Eastern Finland, P.O. Box

16 1627, 70211 Kuopio, Finland

17

18

19 Corresponding author

Department of Forest Sciences, VITRI, FI-00014 University of Helsinki, Helsinki, Finland

21 Email: wafa.abaker@helsinki.fi 
24 Background. Over the last decades sub-Saharan Africa has experienced severe land degradation and food security challenges linked to loss of soil fertility and soil organic matter (SOM), recurrent drought and increasing population. Although primary production in drylands is strictly

27 limited by water availability, nutrient deficiencies, particularly of $\mathrm{N}$ and $\mathrm{P}$, are also considered limiting factors for plant growth. It is known that SOM (often measured as soil organic carbon, SOC) is a key indicator of soil fertility, therefore, management practices that increase SOM contents, such as increasing tree cover, can be expected to improve soil fertility. The objectives of this study were to investigate the effect of Acacia senegal (Senegalia senegal) trees on soil nitrogen $(\mathrm{N})$, phosphorus $(\mathrm{P})$ and potassium $(\mathrm{K})$ in relation to SOC, the potential of $A$. senegal for $\mathrm{N}_{2}$ fixation, and to identify possible $\mathrm{N}$ and $\mathrm{P}$ ecosystem limitations.

Methods. Soil nutrient (total N, P, K and available P and exchangeable K) concentrations and stocks were determined in the $0-10,10-20,20-30$ and $30-50 \mathrm{~cm}$ layers of $A$. senegal plantations of varying age (ranging from 7 to 24-years-old) and adjacent grasslands (reference) at two sites in semi-arid areas of Sudan. At both sites, three plots were established in each grassland and plantation. The potential of $A$. senegal for $\mathrm{N}_{2}$ fixation in relation to plantations age was assessed using $\delta^{15} \mathrm{~N}$ isotopic abundances and nutrient limitations assessed using C:N:P stoichiometry.

Results. Soil concentrations of all studied nutrients were relatively low but were significantly and directly correlated to SOC concentrations. SOC and nutrient concentrations were the highest

42 in the topsoil $(0-10 \mathrm{~cm})$ and increased with plantations age. Acacia foliage $\delta^{15} \mathrm{~N}$ values were $>6$

$43 \%$ and varied little with plantations age. Soil C:N and C:P ratios did not differ between grassland 
44 and plantations and only $0-10 \mathrm{~cm}$ layer $\mathrm{N}: \mathrm{P}$ ratios showed significant differences between 45 grassland and plantations.

46 Discussion. The results indicated that soil fertility in the Sahel region is strongly related to SOM

47 contents and therefore highlighting the importance of trees in the landscape. The higher mineral

48 nutrient concentrations in the topsoil of the plantations may be an indication of "nutrient uplift"

49 by the deeper roots. The high foliar $\delta^{15} \mathrm{~N}$ values indicated that $\mathrm{N}_{2}$ fixation was not an important

50 contributor to soil $\mathrm{N}$ contents in the plantations. The accretion of soil $\mathrm{N}$ cannot be explained by

51 deposition but may be related to inputs of excreted $\mathrm{N}$ brought into the area annually by grazing

52 and browsing animals. The soil C:N:P stoichiometry indicated that the plantations may be

53 limited by $\mathrm{P}$ and the grasslands limited by $\mathrm{N}$. 


\section{Introduction}

Over the last decades sub-Saharan Africa has experienced severe land degradation and food security challenges linked to loss of soil fertility and soil organic matter (SOM), recurrent drought and increasing population (Nkonya et al., 2015). While soil water availability is the main limitation on primary productivity in drylands, nutrient deficiencies, particularly nitrogen $(\mathrm{N})$, phosphorus (P) and potassium (K), are other important causes (FAO, 2004; Lal, 2004a). SOM plays an important role in maintaining adequate nutrients and moisture levels (Tiessen, Cuevas \& Chacon, 1994; Lal, 2004b) and soil fertility management practices that increase SOM contents have been adopted in many drylands in order to enhance crop productivity (FAO, 2004; Koohafkan \& Stewart, 2008). The use of a fallow period is a well-known practice in these areas, allowing the soil to restore its SOM content and so recover from years of cultivation (Sanchez, 1999). However, the area of land put under fallow and the duration of the fallow period have been reduced as a result of increasing population pressure (Kaya, Hildebrand \& Nair, 2000; FAO, 2004). Other practices aimed at reversing land degradation have focused on the role of trees, particularly $\mathrm{N}_{2}$-fixing species, in maintaining soil fertility and protecting the soil from wind and water erosion (FAO, 2001; 2004). The deeper roots of trees play an important role in mineral nutrient recycling, enabling mineral nutrients to be taken up from deeper soil layers and making them available to ground vegetation via litterfall- so-called "nutrient uplift" (Scholes, 1990; Ludwig et al., 2004).

Sub-Saharan drylands are characterized by woodland savanna with trees and shrubs forming an open canopy with varying proportions of grasses (Bourlière \& Hadley, 1983; Torello-Raventos 
92 tree-grass systems has been reported to be greater drier savanna (Dohn et al., 2013; Moustakas et

93 al., 2013). The positive effects of trees and shrubs on ground vegetation have been attributed to

94 the effect of shade, improvement in soil moisture conditions, increased nutrients contents under

95 tree canopies (Belsky et al., 1993; Hagos \& Smit, 2005; Blaser et al., 2013). Fire in savanna is

96 typical, although varying in frequency and intensity, and generally results in a loss of C and $\mathrm{N}$

97 from the ecosystem (Pellegrini et al. 2015). However, fire may have little effect on soil total $\mathrm{N}$

98 and SOC because of the superficial nature of the fires (Coetsee, Bond \& February, 2010;

99 Coetsee, Jacobs \& Govender, 2012). Savanna ecosystems are also subject to grazing and

100 browsing, the effects of which on ecosystem biogeochemistry and nutrient fluxes are complex

101 and variable, but maybe significant (Holdo et al., 2007). In open ecosystems, such as savannas,

102 herbivores may bring in significant quantities of nutrients, particularly $\mathrm{N}$ and $\mathrm{P}$, in the form of

103 dung and urine (Holdo et al., 2007).

$104 \mathrm{~N}_{2}$ fixation can increase soil $\mathrm{N}$ contents (Ludwig et al., 2004; Blaser et al., 2013). However, $\mathrm{N}_{2}$

105 fixation has a high P requirement (Vitousek et al., 2002; Binkley, Senock \& Cromack, 2003),

106 which is low in dryland soils due to P adsorption either by iron oxide (Drenge, 1976) or calcium

107 (Lajtha \& Schlesinger, 1988). The abundance of stable $\mathrm{N}$ isotopes $\left(\delta^{15} \mathrm{~N}\right)$ of leaves and, to a

108 lesser extent, soils can be used to assess $\mathrm{N}_{2}$ fixation and indicate patterns of ecosystem $\mathrm{N}$ cycling

109 (Boddey et al., 2000; Aranibar et al., 2004; Peri et al., 2012). Low foliar and soil $\delta^{15} \mathrm{~N}$ values

110 indicate biological $\mathrm{N}_{2}$ fixation (Schulze et al., 1991; Robinson, 2001), while the enrichment of

111 soil ${ }^{15} \mathrm{~N}$ can be attributed to SOM reprocessing by microorganisms (Aranibar et al., 2004; Swap

112 et al., 2004).

113 The biogeochemical cycles of C, N and P are often closely related (Finzi et al., 2011) and C:N:P

114 stoichiometry is commonly used to provide an insight into the nature of nutrient limitations in 
115 ecosystems (Jobbágy \& Jackson, 2001; Bui \& Henderson, 2013). Soil C:N and C:P ratios are

116 useful indicators of the state of SOM decomposition and N and P availability (Batjes, 1996; Tian

117 et al., 2010) and foliar N:P ratios have been used to assess plant nutrient limitations (Ludwig et

118 al., 2004; Sitters, Edwards \& Olde Venterink, 2013; Blaser et al., 2014).

119 Acacia senegal (L.) Willd. (the new scientific name is Senegalia senegal (L.) Britton.) is a highly 120 drought-resistant tree native to Sudan and Sahel zone of Africa (Obeid \&Seif El Din, 1970).

121 Although the new name has been used in a number of recent publications, we have retained the 122 use of the old name, A. senegal, for reasons of consistency with our previous two related articles 123 and with literature in general, and because of the local importance of the old name. A. senegal 124 provides a wide variety of ecological benefits, such as fodder for animals, fuelwood, and charcoal and economic benefits mainly from gum arabic production (Barbier, 1992). Gum arabic

126 is an exudate collected from $A$. senegal trees and widely used as an emulsifiers in confectionary 127 and beverages, photography, pharmaceutical and other manufacturing industries (Barbier, 2000).

128 This tree is also known to be capable of $\mathrm{N}_{2}$ fixation under different soil types and climatic 129 conditions (Raddad et al., 2005; Gray et al., 2013). The influence of $A$. senegal on soil 130 physiochemical properties in arid and semi-arid areas of Africa has been documented in a 131 number of studies (Deans et al., 1999; Githae, Gachene \& Njoka, 2011). In Sudan, particular 132 attention has been given to SOC and N contents under A. senegal in the north Kordofan region 133 (Jakubaschk, 2002; Olsson and Ardö, 2002; Ardö \& Olsson, 2004; Abaker et al., 2016) and on 134 the influence of inter-cropping systems with $A$. senegal on soil properties of sandy and clay soils 135 (Raddad et al., 2006; El Tahir et al., 2009).

136 The aims of our study were to determine the effects of $A$. senegal plantation age on: 1) soil $\mathrm{N}$ 137 (total), P (total and available) and K (total and exchangeable) concentrations, stocks and 
138 accretion rates; 2) potential $\mathrm{N}_{2}$ fixation using foliar $\delta^{15} \mathrm{~N}$ values, and 3) acacia leaf, ground

139 vegetation $\mathrm{N}: \mathrm{P}$ ratios and soil $\mathrm{C}: \mathrm{N}: \mathrm{P}$ stoichiometry in order to indicate nutrient limitations,

140 imbalances and cycling in these ecosystems. We hypothesized that soil N, P and K

141 concentrations and stocks would be positively correlated with SOC and increase with planation

142 age, further indicating the benefits of maintaining tree cover in these semi-arid environments.

143 This paper complements two previous papers dealing with effects of $A$. senegal plantation age on

144 SOC stocks (Abaker et al., 2016) and on soil moisture and water balance (Abaker, Berninger \&

145 Starr, 2018). These two studies were carried out at the same sites as in this study.

\section{2. Material and Methods}

$147 \quad 2.1$ Study sites

148 We conducted our research at two sites in western Sudan: El Demokeya forest reserve $\left(13^{\circ} 16^{\prime} \mathrm{N}\right.$, $14930^{\circ} 29^{\prime}$ E, $560 \mathrm{~m}$ a.s.1.), an experimental site managed for gum arabic research, and El Hemaira 150 forest $\left(13^{\circ} 19^{\prime} \mathrm{N} 30^{\circ} 10^{\prime} \mathrm{E}, 570 \mathrm{~m}\right.$ a.s.1.) owned and managed by farmers for gum arabic

151 production (Fig. 1). At both sites there was an area of open grassland which was taken to serve as 152 a control against which the plantations of differing age were compared. Photographs showing the 153 plantations and grasslands at the two sites during the rainy season are given in Supplementary 154 material 1.

155 The long-term mean annual rainfall and temperature for both sites is $318 \mathrm{~mm}$ and $27.3^{\circ} \mathrm{C}$. The 156 soils at both sites are classified as Cambic Arenosols (FAO) ( $\geq 90 \%$ sand). The topography is 157 very gently sloping eastwards at El Demokeya and flat at El Hemaira and the hydrology similar 158 at the two sites. Water balance modelled runoff from the grasslands was 32 and $95 \mathrm{~mm}$ for 2011 159 and 2012 respectively, zero for the plantations in 2011 and $63 \mathrm{~mm}$ in 2012 at both sites (Abaker 
160 et al. 2018). Drainage was higher in 2011 than in 2012, and somewhat less at El Hemaira

161 (ranging from 0 to $123 \mathrm{~mm}$ ) than at El Demokeya (ranging from 25 to $128 \mathrm{~mm}$ ). The vegetation

162 at both sites falls within the low rainfall woodland savanna type (Ayoub, 1998; FAO, 2006).

163 Main components of the ground vegetation at both sites were grasses such as Cenchrus biflorus,

164 Aristidia pallida and Eragrostis tremula, and some herbs, including Geigeria alata, Justicia

165 kotschyi, Trianthema pentandra and Acanthus spp. A complete list of ground vegetation species

166 found at the two sites in given in the Supplementary material 2. Although site specific

167 information about grazing and frequency of fire at the two sites is unavailable, it is known that

168 there is over-grazing by sheep and browsing by camels, even within the forest reserve at El

169 Demokeya. Additional information about the study sites and sampling have been described in

170 Abaker et al. (2016).

1712.2 Experimental design, sample plots and sampling

172 The plantations were 15 and 24-years-old (in 2011) at El Demokeya and 7, 15 and 20-years-old

173 at El Hemaira. The same experimental design was used at both sites. Three circular plots (17.8 m

174 radius; 0.1 ha) were established in each plantation of differing age at both sites. Three square

175 plots (50 x $50 \mathrm{~m}$ at El Demokeya and $30 \times 30 \mathrm{~m}$ at El Hemaira) were located in the adjacent

176 grassland, the difference in size being due to the difference in the area of grassland available at

177 the two sites. Square rather than circular plots were used for the grasslands as it was easier to

178 delineate in the field and to carry out the sampling. Although constituting a pseudo-replication

179 experimental design (Hurlbert 1984), which limits the generality of our results concerning

180 general patterns about plantation age effects sensu stricto, the design was determined by the

181 spatial layout of the plantations at the study sites. 
182 Acacia leaf samples were taken from three trees (randomly selected) per plot when the foliage

183 was fully developed. Seven randomly selected terminal branches were collected from each of the

184 three trees, air dried, and the leaves excised and composited by tree $(n=45)$.

185 Ground vegetation samples were collected from one (randomly selected) of the three replicate

186 plots per plantation age and the ground vegetation (a mixture of grasses and herbs) from 14

187 quadrats $\left(1 \times 1 \mathrm{~m}^{2}\right)$ harvested. For the grasslands ground vegetation samples were collected from

188 three quadrats located in one of the grassland plots at each study site. Sampling was carried when 189 the ground vegetation was fully developed. All the plants within each quadrat were manually

190 uprooted, separated into above and belowground parts in the field and placed into separate bags.

191 There were a total of 76 quadrats.

192 Soil samples were taken from the 0-10, 10-20, 20-30 and 30-50 cm layers of all plantation and 193 grassland plots. For each of the plantation plots, samples were taken from under the canopy of 194 one (randomly) selected tree at three distances $(0.5,1$ and $2.5 \mathrm{~m})$ from the stem. For the 195 grassland plots, samples were taken from the four corners and centre of each plot and composited 196 by layer. For determination of bulk density for the grasslands, a separate sample was collected 197 from the centre of only one of the grassland plots at each site.

199 The tree-wise composited acacia leaf samples were further composited by plot for chemical and

$200 \mathrm{~N}$ isotope analyses $(\mathrm{n}=15)$. The above and belowground vegetation biomass samples were dried 201 at $60{ }^{\circ} \mathrm{C}$ for 48 hours and weighed. However, in order to reduce analytical costs, the samples 202 from only five of the 14 quadrats per plantation plot and two of the three quadrats from each of 203 the grassland plots were selected (randomly) for analyses and only the aboveground samples 
204 analysed $(\mathrm{n}=29)$. The soil samples were air-dried and passed through a $2 \mathrm{~mm}$ sieve and the $<2$

$205 \mathrm{~mm}$ fraction saved for analysis. In the case of the soil samples from the plantations, the samples

206 from the three distances from the stem were combined for total elemental analysis, otherwise the

207 other analyses were carried out on the individual samples.

208 Contents of $\mathrm{C}$ and $\mathrm{N}$ in the acacia leaves, vegetation and soil samples were determined directly

209 using an elemental CN analyser (Vario MAX CN, Elementar Analysensysteme GmbH,

210 Germany). Contents of $\mathrm{P}$ and $\mathrm{K}$ were determined by digesting the samples (300 mg plant

211 material, $1 \mathrm{~g}$ soil) in concentrated $\mathrm{HNO}_{3}$ acid $\left(10 \mathrm{ml}+1 \mathrm{ml} \mathrm{H}_{2} \mathrm{O}_{2}\right)$ and microwaving, and

212 measuring elemental concentrations using an ICP-OES spectrometer (Thermo Scientific iCAP

2136000 Series, USA). Particle size analysis of the sieved soil samples was performed using a laser

214 diffraction device (Coulter LS230, Coulter Corporation, Miami, USA) and the percentage of

215 clay, silt and sand fractions calculated. The total elemental and particle size analyses were

216 carried out on oven-dried samples $\left(105^{\circ} \mathrm{C}\right)$. Soil available phosphorous $\left(\mathrm{P}_{\mathrm{av}}\right)$ was extracted using

$2170.5 \mathrm{M}$ sodium bicarbonate solution ( $\mathrm{pH} 8.5)$ and concentrations determined using the

218 Molybdenum blue spectrophotometer method and exchangeable $\mathrm{K}\left(\mathrm{K}_{\mathrm{ex}}\right)$ was extracted with $1 \mathrm{M}$

219 ammonium acetate ( $\mathrm{pH}$ 7.0) and concentrations determined by flame-photometer, both following

220 FAO guidelines (Dewis and Freitas, 1970) and were determined from the air-dried samples.

221 Apparent (also known as "tapped") bulk density was determined using approximately $20 \mathrm{ml}$ of

222 soil placed into a measuring cylinder, tapped 10 times, and the volume and weight of the soil

223 used to calculate the bulk density (Tan, 2005). This method is recommended because of the

224 difficulty in taking intact volumetric samples from loose sandy soils with no structure (Tan,

225 2005), as was the case with our sites. The determination of $P_{a v}, K_{e x}$ and bulk density was made in

226 the laboratory of the Agricultural Research Corporation, Ministry of Agriculture, Sudan while 
227 the total elemental and particle size analyses were carried out in the laboratory of the Department

228 of Forest Sciences, University of Helsinki.

229 The abundance of stable nitrogen isotope, ${ }^{15} \mathrm{~N}$, was determined from the acacia leaf, ground

230 vegetation aboveground biomass and soil (only for one grassland plot per site) samples. $\delta^{15} \mathrm{~N}$

231 values were determined using Continuous-Flow Isotope Ratio Mass Spectrometry (CF-IRMS) at

232 the Centre for Stable isotopes at IMK-IFU/KIT Garmisch-Partenkirchen (Germany). The

233 precision (standard deviation) of internal standard for stable $\mathrm{N}$ isotopic composition was better

234 than $0.2 \%$. The stable isotopic composition of nitrogen is expressed relative to atmospheric $\mathrm{N}_{2}$

235 (international standard for $\mathrm{N}$ ).

\subsection{Calculation of soil stocks and accretion rates}

237 SOC and nutrient stocks $\left(\mathrm{g} \mathrm{m}^{-2}\right)$ were calculated using both the traditional fixed depth method

238 and the minimum equivalent soil mass (ESM) method (Lee et al., 2009). The fixed depth stocks

239 were calculated according to the following equation:

240 Stocks $=$ soil concentration $\mathrm{x}$ BD $\times \mathrm{T} \times 100$

241 where concentration is in $\%, \mathrm{BD}$ is soil bulk density $\left(\mathrm{g} \mathrm{cm}^{-3}\right)$ and $\mathrm{T}$ the thickness of the soil layer

242 (cm). The ESM stocks for each layer were calculated according the equations given by Lee et al.

243 (2009). This was done in order to eliminate the effect of any alteration in bulk density associated

244 with plantation age. The stocks for the four sampling layers were summed to give the stocks for

245 the 0-50 cm layer. Accretion rates of nutrients in the soil were calculated as the difference

246 between the grassland and the oldest plantation fixed depth stocks divided by the age of the

247 plantation. 


\section{$248 \quad 2.5$ Statistical analysis}

249 The effect of plantation age (grassland was taken to be 0 -years-old) on SOC, N, P, $\mathrm{P}_{\mathrm{av}}, \mathrm{K}$ and $\mathrm{K}_{\mathrm{ex}}$

250 concentrations by layer and stocks $(0-50 \mathrm{~cm})$ and on $\mathrm{C}: \mathrm{N}: \mathrm{P}$ ratios by layer were tested for each

251 site separately using one-way analysis of variance (ANOVA) followed by Tukey post-hoc tests.

252 Differences in acacia leaf N, P and K concentrations, N:P ratios and soil and acacia leaf $\delta^{15} \mathrm{~N}$

253 abundances between the 7,15 and 20-year-old plantations at El Hemaria were similarly tested,

254 but for El Demokeya a t-test was performed as there were only plantations of two ages.

255 The dependence of the total soil $\mathrm{N}, \mathrm{P}, \mathrm{P}_{\mathrm{av}}, \mathrm{K}$ and $\mathrm{K}_{\mathrm{ex}}$ on SOC was evaluated by fitting linear

256 regressions and the coefficient of determination $\left(\mathrm{R}^{2}\right)$. Correlations (Pearson) between SOC

257 contents and total N, P, $\mathrm{P}_{\mathrm{av}}, \mathrm{K}$ and $\mathrm{K}_{\mathrm{ex}}$ were computed for each soil layer and site separately. All

258 the statistical analyses were performed using SPSS software (IBM SPSS Statistics for Windows,

259 Version 22.0. Armonk, NY, IBM Corp.).

\section{3. Results}

261 All nutrient concentrations were generally higher in the plantations than in the grasslands,

262 increased with plantations age and decreased with depth (Fig. 2). Concentrations of SOC, N,

263 total $\mathrm{P}$ and $\mathrm{K}_{\mathrm{ex}}$ in the top $(0-10 \mathrm{~cm})$ layer were significantly $(\mathrm{p} \leq 0.05)$ higher in the oldest

264 plantations at both sites compared to the grassland plots. Soil concentrations of total N, P, $\mathrm{P}_{\mathrm{av}}$

265 and $\mathrm{K}_{\mathrm{ex}}$ also significantly depended on SOC concentrations (Fig. 3). The strongest dependence

266 was for $\mathrm{N}\left(\mathrm{R}^{2}=0.90\right)$ and the weakest was for total $\mathrm{K}\left(\mathrm{R}^{2}=0.11\right)$. The correlations between

267 SOC and N concentrations were significant for all layers at both of the sites (Table 1). The

268 correlations between SOC and total P concentrations were significant for all layers at El Hemaira

269 but in the case of El Demokeya the correlation was significant only for the top layer. The 
270 correlations between SOC and total K concentrations were stronger for El Hemaira than El

271 Demokeya. In case of the $\mathrm{P}_{\mathrm{av}}$ and $\mathrm{K}_{\mathrm{ex}}$, significant correlations with SOC were associated with the

272 upper layers.

273 Nutrient stocks in the soil of the plantations were generally greater than those in the grassland 274 and increased with plantation age (Table 2). As the fixed depth SOC stock values showed better 275 relationships with SOC concentrations and with plantation age than did ESM SOC stock values, 276 only the fixed depth stock SOC and nutrient values are presented in Table 2 and handled further.

277 However, the ESM SOC and nutrient stock values are presented in Supplementary material 3. At

278 El Demokeya SOC, N, total $\mathrm{P}$ and $\mathrm{K}_{\mathrm{ex}}$ stocks were significantly higher in the oldest plantation 279 than those in the grassland, but not the $\mathrm{P}_{\mathrm{av}}$ and total $\mathrm{K}$ stocks. At El Hemaira SOC, N and $\mathrm{K}_{\mathrm{ex}}$ stocks were also significantly higher in the oldest plantation than in the grassland. $\mathrm{K}_{\mathrm{ex}}$ stocks in

281 the 15-year-old plantation were also significantly higher than in the grassland. Assuming that the 282 significant difference between grassland and the oldest plantation SOC, N and total P stocks 283 represents the addition of these elements brought about by the effect of the plantation, the 284 average under canopy accretion rates of SOC and N at El Demokeya would be respectively 12.9 285 and $2.0 \mathrm{~g} \mathrm{~m}^{-2} \mathrm{yr}^{-1}$. At El Hemaira, the corresponding SOC and $\mathrm{N}$ accretion rates would be 27.8 286 and $3.0 \mathrm{~g} \mathrm{~m}^{-2} \mathrm{yr}^{-1}$. The total $\mathrm{P}$ accretion rate at El Demokeya would be $0.5 \mathrm{~g} \mathrm{~m}^{-2} \mathrm{yr}^{-1}$ (as the 287 difference in total P stocks between the grassland and oldest plantation at El Hemaira was not 288 significant, the accretion rate is considered zero).

289 Grassland ground vegetation and soil $\delta^{15} \mathrm{~N}$ values were generally lower than corresponding 290 plantation $\delta^{15} \mathrm{~N}$ values. Acacia foliar $\delta^{15} \mathrm{~N}$ values were higher than ground vegetation values, but neither showed a difference related to plantation age (Table 3). The number of ground vegetation samples was too small to allow for significance testing. Soil $\delta^{15} \mathrm{~N}$ values increased with 
293 plantation age and decreased with depth at both study sites, but these trends were not significant

294 ( $\mathrm{p}>0.05$ ). Plantation soil $\delta^{15} \mathrm{~N}$ values were significantly correlated to soil $\mathrm{C}: \mathrm{N}$ ratios, but the

295 relationship for grasslands was clearly different (Fig. 4).

296 Soil C:N:P ratios did not significantly differ with depth and the N:P ratios only showed

297 significant differences between plantation age for the $0-10 \mathrm{~cm}$ layer (Table 4). The $0-10 \mathrm{~cm}$ soil

298 layer C:N and C:P ratios did not show significant differences with age at either of the sites. At El

299 Demokeya, the $0-10 \mathrm{~m}$ soil layer N:P ratio in the 24-year-old plantation was significantly ( $p$

$300<0.05)$ higher than those in the grassland and 15-year-old plantation. At El Hemaira, the $0-10 \mathrm{~cm}$

301 soil layer N:P ratio in 20-year-old plantation was significantly greater $(p<0.05)$ than those in the

302 grassland and 7-year-old plantation. Acacia leaf nutrient concentrations and N:P ratios did not

303 show significant differences related to plantations age at either of the sites (Table 5). There were

304 too few ground vegetation samples for statistical testing of nutrient concentrations and ratios.

\section{4. Discussion}

306 In this study we aimed to determine whether the previously reported increase in SOC contents 307 with plantation age at the two sites (Abaker et al., 2016) would also result in higher nutrient (N,

$308 \mathrm{P}$ and $\mathrm{K}$ ) concentrations and stocks, which would further support the importance of maintaining

309 or increasing tree cover in the region. In an earlier paper, we showed that the increases in SOC

310 with plantation age at the two sites resulted in increased available water capacities which then

311 had an effect on the water balance of the plantations (Abaker, Berninger \& Starr, 2018). Because

312 of the pseudoreplicated design of our study, general patterns about plantation age effects may not

313 be strictly inferred. However, given the inevitable within site variation in site conditions, the

314 climate, soil type and topography were uniform across each site and the replicate three plots for 
315 each treatment (grassland and plantation age) were located so as to be as otherwise similar and

316 comparable as possible. Unfortunately, documented information about land-use prior to the

317 establishment of the plantations at the two sites was not available. However, from discussions

318 with local staff, the forests were established on areas of homogenous abandoned grassland and at

319 various times areas within them planted with Acacia senegal.

320 Recognising the potential limitations imposed by the pseudoreplicated design, the significant

321 dependence of nutrient concentrations on SOC and the significantly higher $\mathrm{N}$ and $\mathrm{K}_{\mathrm{ex}}$ stocks in

322 the oldest plantations compared to the grasslands found in this study nevertheless support our

323 initial hypothesis that soil N, P and K are linked to SOC and are in agreement with results

324 reported from other studies. For example, in A. tortilis savanna woodlands in northern Tanzania

325 Ludwig et al., (2004) found increases in SOM, N, P and $\mathrm{P}_{\mathrm{av}}$ concentrations with tree growth

326 stage (grassland, under small and large trees), and Deans et al., (1999) working with $\mathrm{A}$. senegal

327 in Senegal found that $\mathrm{N}$ and $\mathrm{K}_{\mathrm{ex}}$, but not $\mathrm{P}$ concentrations increased with plantation age. In both

328 these studies, the soil refers to the surface layer $(0-10 \mathrm{~cm})$. This layer had the highest SOC

329 contents and would therefore be expected to be the most affected by the plantations.

330 Furthermore, in the study by Deans et al. (1999), soil concentrations of N, P and $\mathrm{K}_{\mathrm{ex}}$ were all

331 significantly correlated to loss-on-ignition contents, i.e. SOC contents. El Tahir et al. (2009)

332 working at El Demokeya site, reported a SOC stock value of $738 \mathrm{~g} \mathrm{~m}^{-2}$ for 0-30 $\mathrm{cm}$ layer and for

333 total $\mathrm{N}, \mathrm{P}_{\mathrm{av}}$ and $\mathrm{K}_{\mathrm{ex}}$ values of $118,2.5$ and $29 \mathrm{~g} \mathrm{~m}^{-2}$, respectively. We were unable to take into

334 account the effect of fire and grazing on soil SOC and N stocks at our study sites. However, fire

335 has generally been found not to result in a loss of soil total $\mathrm{N}$ and SOC because of the superficial

336 nature of the fires (Coetsee, Bond \& February, 2010; Coetsee, Jacobs \& Govender, 2012). The

337 effect of grazing at our study sites is discussed below in relation to soil $\mathrm{N}$ stocks. 
338 Compared to the grasslands, the higher $\mathrm{N}, \mathrm{P}_{\mathrm{av}}$ and $\mathrm{K}_{\mathrm{ex}}$ concentrations observed in the upper soil

339 layer of the plantations indicates a significant effect of acacia trees on ecosystem nutrient

340 cycling, at least at our study sites. The higher concentrations in the surface layer was particularly

341 obvious in the older plantations and can be explained by "nutrient uplift" by the deeper roots of

342 the acacia trees (Scholes, 1990; Ludwig et al., 2004). Mubarak, Abdalla \& Nortcliff (2012) also

343 concluded that tree litter input is a significant source of $\mathrm{P}$ and $\mathrm{K}$ in southern Kordofan soils and

344 the presence of trees has been shown to contribute to the general maintenance of soil fertility in

345 the Sahel (Wezel, Rajot \& Herbrig, 2000; Schlecht et al., 2006).

346 The higher $\mathrm{N}$ concentrations in the surface soils of the plantations may be thought to be due to

$347 \mathrm{~N}_{2}$ fixation as acacia species are considered to be $\mathrm{N}_{2}$ fixing (Ludwig et al., 2004; Raddad et al.,

348 2005; Boutton \& Liao, 2010). Although, A. senegal has been reported to be a $\mathrm{N}_{2}$ fixer (Raddad et

349 al., 2005; Isaac et al., 2011; Githae et al., 2013; Gray et al., 2013) the high $\delta^{15} \mathrm{~N}$ values we

350 observed for acacia leaves ( $>6 \%$ ) would indicate that $A$. senegal did not fix $\mathrm{N}_{2}$ or is very

351 limited in our sites. If there had been significant $\mathrm{N}_{2}$ fixation in the plantations then one would

352 expect foliar $\delta^{15} \mathrm{~N}$ values to be closer to $0 \%$ (Robinson, 2001; Aranibar et al., 2004; Nardoto et

353 al., 2014). Nevertheless, our acacia foliage $\delta^{15} \mathrm{~N}$ values are in agreement with the findings of

354 other studies conducted in arid environments. For example, Aranibar et al., (2004) observed that

355 Acacia leaves had $\delta^{15} \mathrm{~N}$ values similar to non-legume species and even higher than known $\mathrm{N}_{2^{-}}$

356 fixing species in a study carried in the Kalahari Desert. Pate et al. (1998) reported a mean $\delta^{15} \mathrm{~N}$

357 value of $9.10 \%$ for Acacia species in arid Australia, which was identical to those of non-fixing

358 woody species, suggesting little or absence of $\mathrm{N}$ fixation. In a study carried out in Acacia tortilis

359 savanna woodlands in Kenya, Belsky et al. (1993) concluded that that $\mathrm{N}_{2}$ fixation was not an

360 important contributor of $\mathrm{N}$ to the soil. $\mathrm{N}_{2}$ fixation by legume trees in drylands has been show to 
361 vary considerably, even within the same species (Nygren et al., 2012). For example, $\mathrm{N}_{2}$ fixation

362 by $A$. senegal growing on clay soil in Sudan was shown to vary from 29 to $48 \mathrm{~kg} \mathrm{~N} \mathrm{ha}^{-1}$ (Raddad 363 et al., 2005).

364 Our soil $\mathrm{N}$ accretion rates in the plantations appear high but are comparable to those reported by 365 Blaser et al. (2014) of 1.3-2.0 $\mathrm{g} \mathrm{N} \mathrm{m}^{-2} \mathrm{yr}^{-1}$ (for 0-10 $\mathrm{cm}$ layer) in Zambian savanna. However, 366 the vegetation at their site was dominated by the $\mathrm{N}_{2}$-fixing shrub Dichrostachys cinerea. As 367 deposition loads of $\mathrm{N}$ in the Sahel are about 0.3-0.7 $\mathrm{g} \mathrm{N} \mathrm{m}^{-2} \mathrm{yr}^{-1}$ (Delon et al., 2010), our high $\mathrm{N}$ 368 accretion rates cannot be explained by deposition. The paradox between the accumulation of soil $369 \mathrm{~N}$ in the absence of $\mathrm{N}_{2}$ fixation and sufficient $\mathrm{N}$ deposition in humid tropical forests has been 370 identified in several studies (see Hedin et al., 2009) and has been explained by heterotrophic $\mathrm{N}_{2}$

371 fixation by free-living bacteria decomposing litter and SOM (Vitousek \& Hobbie, 2000) or by

372 canopy epiphytic $\mathrm{N}_{2}$ fixation (Hedin et al., 2009). However, the rates of such $\mathrm{N}_{2}$ fixation are low 373 and could not explain our high soil $\mathrm{N}$ accretion rates. A possible source of our observed high soil

$374 \mathrm{~N}$ accretion rates could be from grazing animal excretion. The two study sites are not fenced and 375 seasonal pastoral and nomadic grazing (mainly sheep) and browsing (camels), although varying, 376 takes place throughout the study area (Poussart, Ardö \& Olsson, 2004). Bigger trees (older 377 plantations) may be expected to provide increased shading and ground vegetation for grazing and 378 browsing. Animals entering the plantations may therefore have added $\mathrm{N}$ to the soil in the form of 379 animal excretion derived from grazing outside and in excess of grazing removals from inside the 380 study sites. Studies on with elk and bison in north-temperate grassland indicate that herbivore excretion can add significant amounts of $\mathrm{N}$ to the soil (Frank et al., 1994). However, data on land-use history and animal herbivory at the two sites is not available and therefore this animal excretion $\mathrm{N}$ explanation is only speculative. 
384 It has been shown that N-fixing trees accumulate large amount of N-rich litterfall during the first

385 years of establishment, however once $\mathrm{N}$ availability has built up in the soil, $\mathrm{N}$ fixation may be

386 ceased or inhibited (Khanna, 1998; Boddey et al., 2000; Hedin et al., 2009) and the older

387 trees/plantations become more dependent on litterfall and $\mathrm{N}$ recycling (Deans et al., 2003). The

388 relatively high and increasing trend in soil $\delta^{15} \mathrm{~N}$ with plantation age at our sites is an indication of

389 greater microbiological processing of SOM and a more open N cycle (ammonia volatilization

390 and denitrification during the wet season) resulting in an enrichment of ${ }^{15} \mathrm{~N}$ (Aranibar et al.,

391 2004; Swap et al., 2004; Hobbie \& Ouimette, 2009). The negative relationship observed between

392 soil $\delta^{15} \mathrm{~N}$ and soil $\mathrm{C}: \mathrm{N}$ ratios in the plantations is consistent with the notion that low soil C:N

393 ratios in arid environments promote greater N gaseous losses (Austin \& Vitousek, 1998;

394 Aranibar et al., 2004; Saiz et al., 2016). The vegetation present at a given site exerts a large

395 influence on SOM dynamics not only because of the quantity and quality of organic matter

396 returning to the soil (Saiz et al., 2015), but also because of its impact on soil hydrological

397 conditions (Abaker, Berninger \& Starr, 2018). In this regard, trees growing on coarse-textured

398 soils in semi-arid regions may promote the maintenance of soil water conditions suitable for the

399 activities of SOM decomposers through the interception and funnelling of rainfall by their

400 canopies and the reduction in soil water evaporation by shading (Bargués Tobella et al., 2014;

401 Ilstedt et al., 2016). Two recent works have shown potentially faster SOM decomposition rates at

402 locations dominated by trees compared to those dominated by grass vegetation in mixed $\mathrm{C}_{3} / \mathrm{C}_{4}$

403 systems occurring on coarse-textured soils (Saiz et al., 2015; 2016). These vegetation-related

404 factors may be responsible for the higher SOC and nutrient contents observed in our acacia

405 plantations. The higher soil $\delta^{15} \mathrm{~N}$ values observed with plantation age is further evidence of SOM

406 decomposition processes being comparatively more dynamic under the direct influence of trees. 
407 Cyanobacteria associated with the formation of cryptogamic soil crusts have been shown to be a

408 significant pathway to fix atmospheric $\mathrm{N}_{2}$ in arid environments, but their development

409 diminishes with vegetation cover (Aranibar et al., 2004; Wang et al., 2013). Therefore, N

410 fixation by cyanobacterial soil crusts (which may be expected to be more strongly developed in

411 the grasslands) may explain the low soil $\delta^{15} \mathrm{~N}$ values observed in grassland sites. However, we

412 have no information on the presence and development of such cyanobacterial soil crusts at our

413 sites, but in any case annual $\mathrm{N}$ fixation rates associated with cyanobacterial soil crusts are very

414 low (Aranibar et al., 2003).

415 The decreasing rather than increasing trend in soil $\delta^{15} \mathrm{~N}$ with depth observed in both the 416 grasslands and plantations is somewhat unusual (Hobbie \& Ouimette, 2009), but it has also been

417 shown during the wet season in an arid, sandy site in the Kalahari (Wang et al., 2013). The

418 variation in soil $\delta^{15} \mathrm{~N}$ values with depth are the result of multiple interacting factors, which

419 include $\mathrm{N}$ inputs by plant and cryptogamic crusts, vertical transport processes (i.e. leaching,

420 fungal immobilization and bioturbation), soil moisture conditions, and isotopically fractionating

421 processes (e.g. ammonia volatilization and denitrification) (Hobbie \& Ouimette, 2009; Wang et

422 al., 2013; Saiz et al., 2016). However, as the $\mathrm{N}$ contents in our soils are very low resulting in a

423 low analytical signal for ${ }^{15} \mathrm{~N}$, our soil $\delta^{15} \mathrm{~N}$ results should be interpreted with caution.

424 Soil C:N ratios often decrease with soil depth as a result of the SOM being older and more

425 decomposed and therefore relatively enriched in N compared to SOC (Batjes, 1996; Tian et al.,

426 2010). However, there was no consistent trend in $\mathrm{C}: \mathrm{N}$ ratios with depth in either the grasslands

427 or the plantations at our sites, which may be explained by gaseous losses of $\mathrm{N}$ as indicated by the

428 soil $\delta^{15} \mathrm{~N}$ values and discussed above. The significantly lower soil $(0-10 \mathrm{~cm}) \mathrm{N}: \mathrm{P}$ ratios in the

429 grasslands than in the oldest plantations at our sites, however, would indicate $\mathrm{N}$ limitation in the 
430 grasslands. The N:P ratios of the ground vegetation were on the lower side of values presented

431 for savanna grasses by Ludwig et al., (2004) and Sitters, Edwards \& Olde Venterink (2013).

432 Ludwig et al. (2004) considered low grass N:P ratios from open grasslands to indicate N

433 limitation and the higher values for grasses sampled from under the canopy of trees to indicate P-

434 limiting conditions for the grasses. Sitters, Edwards \& Olde Venterink (2013) similarly

435 concluded that the increase in grass N:P ratios with tree density indicates a shift towards P-

436 limiting conditions for the ground vegetation.

\section{5. Conclusions}

438 The concentrations of all studied nutrients were relatively low but directly and significantly 439 correlated to SOC, were highest in the topsoil and increased with plantation age at our sites.

440 Although these results are specific to our study sites, we consider these results support our

441 hypothesis that soil N, P and K contents in the Sahel region are strongly controlled by SOM

442 (SOC) contents. Although $A$. senegal is known to be capable of $\mathrm{N}_{2}$ fixation and may have

443 occurred when the trees were young, current foliar $\delta^{15} \mathrm{~N}$ values did not indicate ongoing $\mathrm{N}_{2}$

444 fixation in the plantations. The soil $\mathrm{N}$ accretion rates observed in the plantations was unlikely to

445 be due to $\mathrm{N}$ deposition but may be related to inputs of excreted $\mathrm{N}$ brought into the area annually

446 by grazing and browsing animals. The relatively high surface soil $\mathrm{N}$ contents in the plantations at

447 our sites were considered to be the result of litterfall and recycling. The higher total and plant

448 available contents of $\mathrm{P}$ and $\mathrm{K}$ in the soil surface of the plantations may be an indication of

449 "nutrient uplift" by the deeper roots of the acacia trees. Soil N:P ratios indicated N limitation in

450 the grasslands and a trend towards P-limitation in the plantations. Our results support the notion

451 that an increase in SOM (SOC) contents related to the retention and preferably planting of trees 
452 in the Sahel region would not only increase carbon sequestration, but also significantly improve 453 soil fertility.

\section{Acknowledgements}

455 We would like to thank the staff of El Obeid Agricultural Research Station, Sudan for their

456 logistic support and help with the fieldwork. We appreciate the technical assistance by laboratory

457 technician Marjut Wallner during the analysis of the samples at the Department of Forest

458 Sciences, University of Helsinki. We also thank Mr Victor Braojos for his assistance with the

459 isotope analysis.

460

461

462

463

464

465

466

467

468 References 
469 Abaker, W.E., Berninger, F., Saiz, G., Braojos, V., Starr, M., 2016. Contribution of Acacia 470 senegal to biomass and soil carbon in plantations of varying age in Sudan. Forest Ecology and Management 368, 71-80.

472

473

474

475

476

477

478
Abaker, W.E., Berninger, F., Starr, M. Changes in soil hydraulic properties, soil moisture and water balance in Acacia senegal plantations of varying age in Sudan. Journal of Arid Environments 150, 42-53.

Aranibar, J.N, Anderson, I.C., Ringrose, S., Macko, S.A., 2003. Importance of nitrogen fixation in soil crusts of Southern African arid ecosystems: acetylene reduction and stable isotope studies. Journal of Arid Environments 54, 345-358.

Aranibar, J.N., Otter, L., Macko, S.A., Feral, C.J. W., Epstein, H.E., Dowty, P.R., Eckardt, F., Shugart, H.H., Swap, R.J., 2004. Nitrogen cycling in the soil-plant system along a precipitation gradient in the Kalahari sands, Global Change Biology 10, 359-373.

Ardö, J., Olsson, L., 2004. Soil carbon sequestration in traditional farming in Sudanese dry lands. Environmental Management 33(1), 318-329.

Austin, A.T., Vitousek, P., 1998. Nutrient dynamics on a precipitation gradient in Hawai'i, Oecologia 113, 519-529.

Ayoub, A.T., 1998. Extent, severity and causative factors of land degradation in the

Sudan. Journal of Arid Environments 38, 397-409.

Barbier, E.B., 1992. Rehabilitating gum arabic systems in Sudan: economic and environmental implications. Environmental and Resource Economics 2, 341-358.

Barbier, E.B., 2000. The economic linkages between rural poverty and land degradation: some evidence from Africa. Agriculture Ecosystems and Environment 82, 355-370. 
491 Bargués Tobella, A., Reese, H., Almaw, A., Bayala, J., Malmer, A., Laudon, H., Ilstedt, U., 2014.

492

493

494

495

496

497

498

499

500

501

502

503

504

505

506

507

508

509

510

511

512
The effect of trees on preferential flow and soil infiltrability in an agroforestry parkland in semiarid Burkina Faso. Water Resources Research 50, 3342- 3354. doi:http://dx.doi.org/10.1002/2013WR015197.

Batjes, N.H., 1996. Total carbon and nitrogen in the soils of the world. European Journal of Soil Sciences 47, 151-163.

Belsky, A.J., Mwonga, S.M., Amundson, R.G., Duxbury, J.M., Ali, A.R., 1993. Comparative effects of isolated trees on their undercanopy environments in high- and low-rainfall savannas. Journal of Applied Ecology 30, 143-155.

Binkley, D., Senock, R., Cromack, K., 2003. Phosphorus limitation on nitrogen fixation by Facaltaria seedlings. Forest Ecology and Management 186, 171-176.

Blaser, W.J., Sitters, J., Hart, S.P., Edwards, P.J., Olde Venterink, H., 2013. Facilitative or competitive effects of woody plants on understorey vegetation depend on $\mathrm{N}$ fixation, canopy shape and rainfall. Journal of Ecology 101, 1598-1603.

Blaser, W.J., Shanungu, G.K., Edwards, P.J., Olde Venterink, H., 2014. Woody encroachment reduces nutrient limitation and promotes soil carbon sequestration. Ecology and Evolution 4(8), 1423-1438 doi:10.1002/ece3.1024

Boddey, R.M, Peoples, M.B., Palmer, B., Dart, P.J., 2000. Use of the ${ }^{15} \mathrm{~N}$ natural abundance technique to quantify biological nitrogen fixation by woody perennials. Nutrient Cycling in Agroecosystems 57, 235-70.

Bourlière, F., Hadley M., 1983. Present-day savannas: an overview. In: Ecosystems of the World. 13. Tropical Savannas, F. Bourlière. (Ed.), Elsevier, Amsterdam, 17 pp. 
513 Boutton, T.W, Liao, J.D., 2010. Changes in soil nitrogen storage and $\delta^{15} \mathrm{~N}$ with woody plant

514 encroachment in a subtropical savanna parkland landscape. Journal of Geophysical Research $515 \quad$ 115:G03019.

516 Bui, E.N., Henderson, B.L., 2013. C:N:P stoichiometry in Australian soils with respect to 517 vegetation and environmental factors. Plant Soil 373, 553-568.

518 Coetsee, C., Bond, W.J., February, E.C., 2010. Frequent fire affects soil nitrogen and carbon in an 519 African savanna by changing woody cover. Oecologia 162, 1027-1034. DOI 520 10.1007/s00442-009-1490-y

521 Coetsee, C., Jacobs, S., Govender, N., 2012. An Overview of Nitrogen Cycling in a Semiarid 522 Savanna: Some Implications for Management and Conservation in a Large African Park. Environmental Management 49, 387-402.

524 $59,499-510$.

Deans, J.D., Diagne, O., Nizinski, J., Lindley, D.K., Seek, M., Ingleby, K., Munro, R.C., 2003. Comparative growth, biomass production, nutrient use and soil amelioration by nitrogen fixing-tree species in semi-arid Senegal. Forest Ecology Management. 176, 253-264.

Delon, C., Galy-Lacaux, C., Boone, A., Liousse, C., Serça, D., Adon, M., Diop, B., Akpo, A., 531 Lavenu, F., Mougin, E., Timouk, F., 2010. Atmospheric nitrogen budget in Sahelian dry savannas. Atmospheric Chemistry and Physics 10, 2691-2708. Soils Bulletin 10. FAO, Rome. 
535 Dohn, J., Dembélé, F., Karembé, M., Moustakas, A., Amévor, K.A., Hanan, N.P., 2013. Tree

536 effects on grass growth in savannas: competition, facilitation and the stress-gradient 537 hypothesis. Journal of Ecology 101, 202-209.

538 Dregne, H.E., 1976. Soils of Arid Regions. Elsevier, Amsterdam. pp. 237.

539 El Tahir, B.A., Ahmed, D.M., Ardö, J., Gaafar, A.M., Salih, A.A., 2009. Changes in soil properties 540 following conversion of Acacia senegal plantation to other land management systems in 541 North Kordofan State, Sudan. Journal of Arid Environments 73, 499-505.

542 FAO 2001. Soil carbon sequestration for improved land management. World Soil Resources 543 Reports 96. FAO, Rome.

544 FAO, 2004. Carbon sequestration in dryland soils. World Soil Resources Reports 102. Rome, Italy.

545 FAO, 2006. Global forest resources assessment 2005. Estimating forest cover and forest cover 546 change in Sudan. Working paper 109/E. FAO, Rome.

547 Finzi, A.C., Austin, A.T., Cleland, E.E., Frey, S.D., Houlton, B.Z., Wallenstein, M.D., 2011.

548 Coupled biochemical cycles: responses and feedbacks of coupled biogeochemical cycles to 549 climate change. Examples from terrestrial ecosystems. Frontiers in Ecology and $550 \quad$ Environment 9, 61-67.

551 Frank, D.A., Inouye, R.S., Huntly, N., Minshall, G.W., Anderson, J.E., 1994. The biogeochemistry 552 of a north-temperate grassland with native ungulates: nitrogen dynamics in Yellowstone $553 \quad$ National Park. Biogeochemistry 26: 163-188.

554 Githae, E.W, Gachene, C. K.K, Njoka, J.T., 2011. Soil physicochemical properties under Acacia 555 senegal varieties in the dryland areas of Kenya. African Journal of Plant Science 5(8), 475556 482. 
557 Githae, E.W., Gachene, C.K.K., Njoka, J.T., Omondi, S.F., 2013. Nitrogen fixation by natural 558 populations of Acacia senegal in the drylands of Kenya using ${ }^{15} \mathrm{~N}$ natural abundance. Arid $559 \quad$ Land Research and Management 27, 327-336.

560 Gray, A., David, O., Cavers, S., Wilson, J., Telford, A., Grant, F., Diouf, M., Ochieng, J., Grant, 561 H., Stott, A., 2013. Does geographic origin dictate ecological strategies in Acacia Senegal 562 (L.) Willd.? Evidence from carbon and nitrogen stable isotopes. Plant and Soil 369, 479563 496.

564 565

566

567 568 569

570

571

572 573

574 575

576

577 578

Hagos, M.G., Smit, G.N., 2005. Soil enrichment by Acacia mellifera subsp. detinens on nutrient poor sandy soil in a semi-arid southern African savanna. Journal of Arid Environment 61, 47-59.

Hedin, L.O., Brookshire, E.N.J., Menge, D.N.L., Barron, A.R., 2009. The nitrogen paradox in tropical forest ecosystems. Annual Review of Ecology, Evolution and Systematics 40, 613635.

Hurlbert, S.H., 1984. Pseudoreplication and the design of ecological field experiments. Ecological Monographs 54, 187-211.

Hobbie, E.A., Ouimette, A.P., 2009. Controls of nitrogen isotope patterns in soil profiles. Biogeochemistry 95, 355-371.

Holdo, R.M., Holt, R.D., Coughenour, M.B., Ritchie, M.E., 2007. Plant productivity and soil nitrogen as a function of grazing, migration and fire in an African savanna. Journal of Ecology 95, 115-128.

Ilstedt, U., Bargués Tobella, A., Bazié, H.R., Bayala, J., Verbeeten, E., Nyberg, G., Sanou, J., Benegas, L., Murdiyarso, D., Laudon, H., Sheil, D., Malmer, A., 2016. Intermediate tree 
cover can maximize groundwater recharge in the seasonally dry tropics. Scientific Reports

580 $6,21930$.

581

582

583

584 585

586

587

588

589

590

591

592

593

594

595

596

597

598

Isaac, M.E, Harmand, J.M., Lesueur, D., Lelon, J., 2011. Tree age and soil phosphorus conditions influence $\mathrm{N}_{2}$-fixation rates and soil $\mathrm{N}$ dynamics in natural populations of Acacia senegal. Forest Ecology Management 261, 582-588.

Jakubaschk, C., 2002. Acacia senegal, soil organic carbon and nitrogen contents: A study in North Kordofan, Sudan. M.Sc. thesis. Department of Physical Geography and Ecosystems Analysis, Lund University, Lund.

Jobbágy, E.G, Jackson, R.B., 2001. The distribution of soil nutrients with depth: global patterns and the imprint of plants. Biogeochemistry 53, 51-77.

Kaya, B., Hildebrand, P.E., Nair, P.K., 2000. Modeling changes in farming systems with the adoption of improved fallows in southern Mali. Agricultural Systems 66, 51-68.

Khanna, P.K., 1998 Nutrient cycling under mixed-species tree systems in Southeast Asia. Agroforest Systems 38, 99-120.

Koohafkan, P., Stewart, B.A., 2008. Water and Cereals in Drylands. FAO, Malta, Italy.

Lajtha, K., Schlesinger, W.H., 1988. The biogeochemistry of phosphorus cycling and phosphorus availability along a desert soil chronosequence. Ecology 69, 24-39.

Lal, R., 2004a. Carbon Sequestration in Dryland Ecosystems. Environmental Management 33(4), $528-544$.

Lal, R., 2004b. Soil carbon sequestration to mitigate climate change. Geoderma 123, 1-22. 
599 Lee, J., Hopmans, J.W., Rolston, D.E., Baer, S.G., Six, J., 2009. Determining soil carbon stock 600 changes: Simple bulk density corrections fail. Agriculture, Ecosystems and Environment $601 \quad 134,251-256$.

602 Ludwig, F., de Kroon, H., Berendse, F., Prins, H.H.T., 2004. The influence of savanna trees on 603 nutrient, water and light availability and the understorey vegetation. Plant Ecology 170, 93$604 \quad 105$.

605

606

607

608

609

610

611

612

613

614

615

616

617

618

619

Moustakas, A., Kunin, W.E., Cameron, T.C., Sankaran, M., 2013. Facilitation or competition? Tree effects on grass biomass across a precipitation gradient. PLoS ONE, 8(2), e57025.

Mubarak, A.R., Abdalla, M.H. Nortcliff, S., 2012. Millet (Pennisetum typhoides) yield and selected soil attributes as influenced by some tree types of the semi-arid tropics of Sudan. Journal of Arid Environments 77, 96-102.

Nardoto, G.B., Quesada, C.A., Patiño, S., Saiz, G., Baker, T.R., Schwarz, M., Schrodt, F., Feldpausch, T.R., Domingues, T.F., Marimon, B.S., Marimon Junior, B.H., Vieira, I.C.G., Silveira, M., Bird, M.I., Phillips, O.L., Lloyd, J., Martinelli, L.A., 2014. Basin-wide variations in Amazon forest nitrogen-cycling characteristics as inferred from plant and soil ${ }^{15} \mathrm{~N}:{ }^{14} \mathrm{~N}$ measurements. Plant Ecology and Diversity 7, 173-187.

Nkonya, E., Johnson, T., Kwon; H.Y., Kato, E., 2015. Economics of Land Degradation in SubSaharan Africa. In Economics of land degradation and improvement - a global assessment for sustainable development, Nkonya, E., Mirzabaev, A., von Braun, J (eds). International Food Policy Research Institute, Washington, DC, USA, Center for Development Research, University of Bonn: Germany, Ch. 9; 215-259. 
620 Nygren, P., Fernández, M.P., Harmand, J-M., Leblanc, H.A., 2012. Symbiotic dinitrogen fixation

621 by trees: an underestimated resource in agroforestry systems? Nutrient Cycling in $622 \quad$ Agroecosystems 94, 123-160.

623 Olsson, L., Ardö, J., 2002. Soil carbon sequestration in degraded semiarid agro-ecosystems - perils 624 and potentials. Ambio 31, 471-477.

625 Pate, J.S., Unkovich, M.J., Erskine, P.D., Stewart G.R., 1998. Australian mulga ecosystems $-{ }^{13}$ C 626 and ${ }^{15} \mathrm{~N}$ natural abundances of biota components and their ecophysiological significance. 627 Plant, Cell and Environment 21, 1231-1242.

628 Pellegrini, A.F.A., Hedin, L.O., Staver, A.C., Govender, N., 2015. Fire alters ecosystem carbon 629 and nutrients but not plant nutrient stoichiometry or composition in tropical savanna. $630 \quad$ Ecology $96,1275-1285$.

631 Peri, P.L., Ladd, B., Pepper, D.A., Bonser, S.P., Laffan, S.W., Amelung, W., 2012. Carbon $\left(\delta^{13}\right.$ C) 632 and nitrogen $\left(\delta^{15} \mathrm{~N}\right)$ stable isotope composition in plant and soil in Southern Patagonia's 633 native forests. Global Change Biology 18, 311-321.

634 Poussart, J.N., Ardö, J., Olsson, L., 2004. Effects of data uncertainties on estimated soil organic 635 carbon in the Sudan. Environmental Management 33(1), 405-415.

636 Obeid, M., Seif El Din, A., 1970. Ecological studies of vegetation of Sudan.I. Acacia-senegal (L.) 637 Willd. And its natural regeneration. Journal of Applied Ecology 7, 507-518.

638 Raddad EAY, Salih AA, El Fadl MA, Kaarakka V, Luukkanen O., 2005. Symbiotic nitrogen 639 fixation in eight Acacia senegal provenances in dryland clays of the Blue Nile Sudan 640 estimated by the ${ }^{15} \mathrm{~N}$ natural abundance method. Plant and Soil 275, 261-269. 
641 Raddad, E.Y., Luukkanen, O., Sali, A.A., Kaarakka, V., El Fadl, M.A., 2006. Productivity and 642 nutrient cycling in young $A$. senegal farming systems on Vertisol in the Blue Nile region. Sudan. Agroforestry Systems. 68, 193-207.

644

645

646

647

648

649

650

651

652

653

654

655

656

657

658

659

660

Robinson, D., 2001. $\delta^{15} \mathrm{~N}$ as an integrator of the nitrogen cycle, Trends in Ecology and Evolution $16(3), 153-162$.

Saiz, G., Bird, M.I., Wurster, C.M., Quesada, C.A., Ascough, P.L., Domingues, T.F., Schrodt, F., Schwarz, M., Feldpausch, T.R., Veenendaal, E.M., Djagbletey, G., Jacobsen, G., Hien, F., Compaore, H., Diallo, A., Lloyd, J. 2015. The influence of $\mathrm{C}_{3}$ and $\mathrm{C}_{4}$ vegetation on soil organic matter dynamics in contrasting semi-natural tropical ecosystems. Biogeosciences 12, 5041-5059.

Saiz, G., Wandera, F.M., Pelster, D.E., Ngetich, W., Okalebo, J.R., Rufino, M.C., ButterbachBahl, K., 2016. Long-term assessment of soil and water conservation measures (Fanya-juu terraces) on soil organic matter in South Eastern Kenya. Geoderma 274, 1-9.

Sanchez, P.A., 1999. Improved fallow comes of age in the tropics. Agroforestry Systems 47, 312.

Schlecht, E., Buerkert, M., Tielkes, E., Bationo, A., 2006. A critical analysis of challenges and opportunities for soil fertility restoration in Sudano-Sahelian West Africa. Nutrient Cycling in Agroecosystems 76, 109-136.

Scholes, R.J., 1990. The influence of soil fertility on the ecology of African savannas. Journal of Biogeography 17, 415-419. 
661 Schulze, E.D., Farquhar, G.D., Miller, J.M., Schulze, W., Walker, B., Williams, R.J., 1999.

662

663

664

665

666

667

668

669

670

671

672

673

674

675

676

677

678

679

680

681

Interpretation of increased foliar $\mathrm{d} 15 \mathrm{~N}$ in woody species along a rainfall gradient in northern Australia. Australian Journal of Plant Physiology 26, 296-298.

Sitters, J., Edwards, P.J., Olde Venterink, H., 2013. Increases of soil C, N, and P pools along an Acacia tree density gradient and their effects on trees and grasses. Ecosystems 16, 347-357.

Swap, R.J., Aranibar, J.N., Dowty, P.R., Gilhooly, W.P., Macko, S.A., 2004. Natural abundance of ${ }^{13} \mathrm{C}$ and ${ }^{15} \mathrm{~N}$ in $\mathrm{C}_{3}$ and $\mathrm{C}_{4}$ vegetation of southern Africa: patterns and implications. Global Change Biology 10, 350-358. doi: 10.1046/j.1529-8817.2003.00702.x

Tan. K.H., 2005. Soil Sampling, Preparation, and Analysis. Second Edition. Boca Raton, Florida, USA: Taylor and Francis, pp. 680.

Tian, H., Chen, G., Zhang, C., Melillo, J.M., Hall, C.A., 2010. Pattern and variation of C: N: P ratios in China's soils: a synthesis of observational data. Biogeochemistry 98(1-3), 139-151.

Tiessen, H., Cuevas, E., Chacon, P., 1994. The role of soil organic matter in sustaining soil fertility. Nature 371, 783-785.

Torello-Raventosa, M., Feldpausch, T.R., Veenendaal, E., Schrodt, F., Saiz, G., Domingues, T.R., Djagbletey, G., Ford, A., Kemp, J., Marimon, B.S., Marimon Junior, B.H., Lenza, E., Ratter, J.A., Maracahipes, L., Sasaki, D., Sonk'e, B., Zapfack, L., Taedoumg, H., Villarroel, D., Schwarz, M., Quesada, C.A., Ishida, F.Y., Nardoto, G.B., Affum-Baffoe, K., Arroyo, L., Bowman, D.M.J.S., Compaore, H., Davies, K., Diallo, A., Fyllas, N.M., Gilpin, M., Hien, F., Johnson, M., Killeen, T.J., Metcalfe, D., Miranda, H.S., Steininger, M., Thomson, J., Sykora, K., Mougin, E., Hiernaux, P., Bird, M.I., Grace, J., Lewis, S.L., Phillips, O.L., and 
682 Lloyd, J., 2013. On the delineation of tropical vegetation types with an emphasis on 683 forest/savanna transitions. Plant Ecology and Diversity 6, 101-137.

684 Vitousek, P.M., Hobbie, S., 2000. Heterotrophic nitrogen fixation in decomposing litter: patterns 685 and regulation. Ecology 81 (9), 2366-2376.

686 Vitousek, P.M., Cassman, K., Cleveland, C., Crews, T., Field, C.B., Grimm, N.B., Howarth, R.W., 687 Marino, R., Martinelli, L., Rastetter, E.B., Sprent, J.I., 2002. Towards an ecological 688 understanding of biological nitrogen fixation. Biogeochemistry 57, 1-45.

689 Wezel, A., Rajot, J.L., Herbrig, C., 2000. Influence of shrubs on soil characteristics and their 690 function in Sahelian agro-ecosystems in semi-arid Niger. Journal of Arid Environments 44, $691 \quad 383-398$.

692 Wang, L., Okin, G.S., D’Odorico, P., Caylor, K.K., Macko, S.A. 2013. Ecosystem-scale spatial 693 heterogeneity of stable isotopes of soil nitrogen in African savannas. Landscape Ecology 694 28(4), 685-698. 
Figure 1

Satellite images (Image: ( 2017 Google, DigitalGlobe and CNES/Airbus) of the two study sites El Demokeya (A) and El Hemaira (B) showing location of the plots.

Number preceding the underscore refers to plantation age in years $(0=$ grassland) and number following the underscore refers to plot number. Inset maps showing Sudan's location in Africa (C) and location of study sites in Sudan (D).

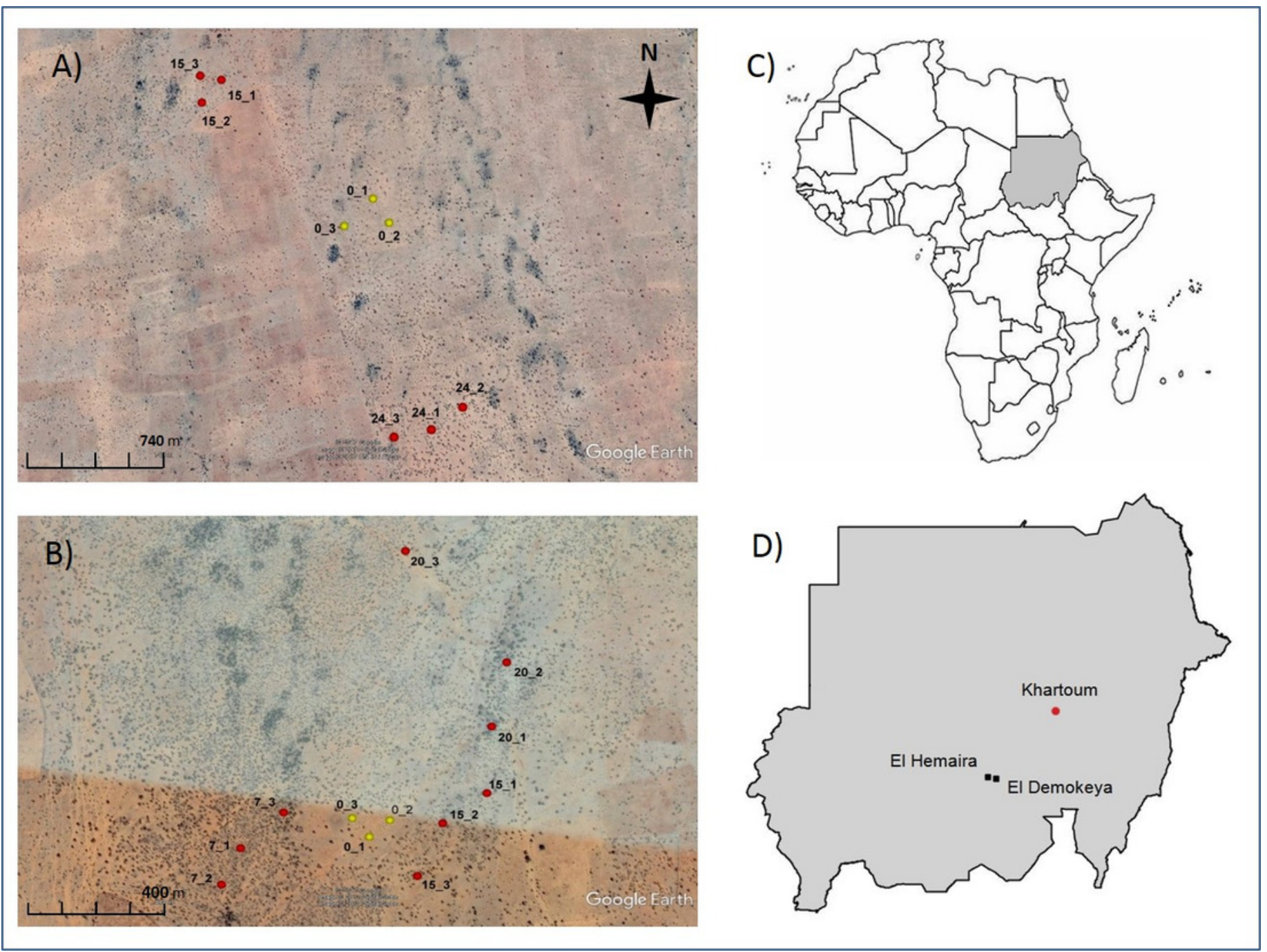


Figure 2 (on next page)

Soil SOC, N, total $P$, available $P$, total $K$ and extractable $K$ mean $(n=3)$ concentrations plotted against depth for grassland and plantations by age for El Demokeya (A-F) and El Hemaira (G-L) sites.

SOC data from Abaker et al. (2016). 
A

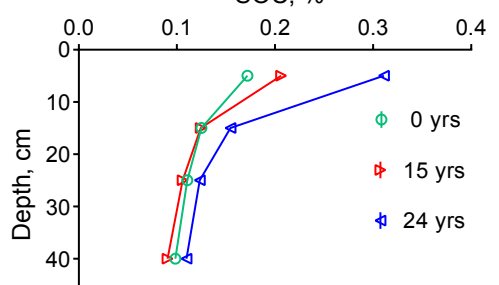

PeerJ

B

N, \%

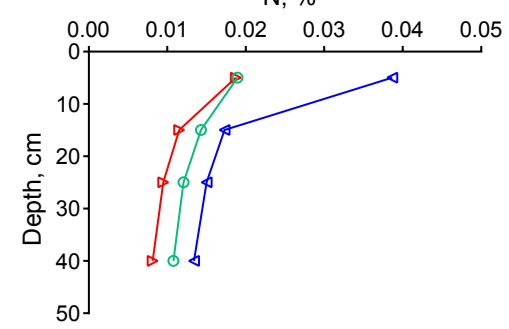

C

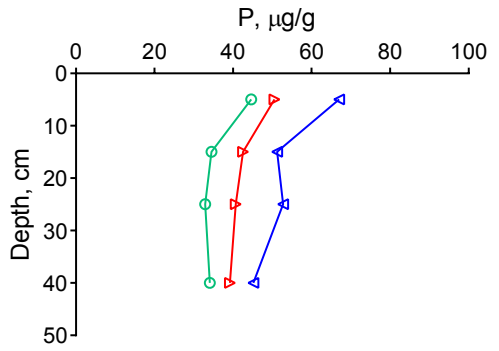

D

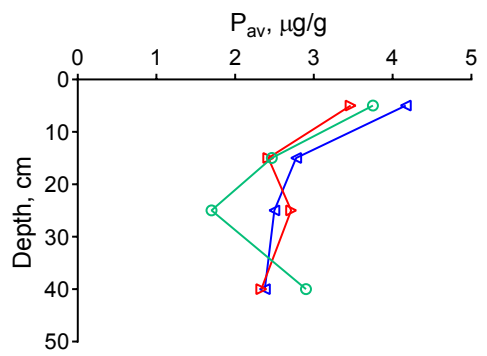

E

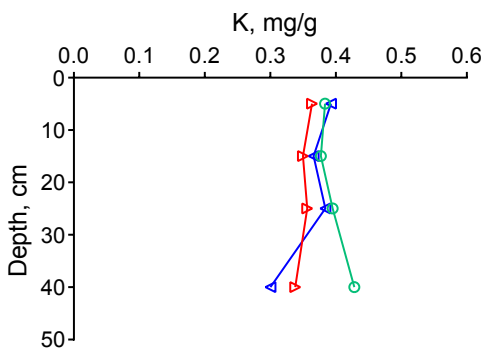

F

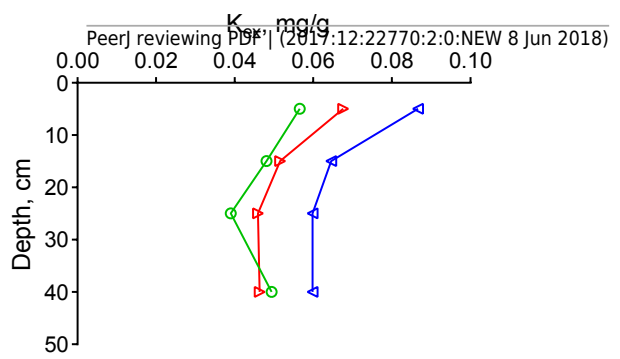

G

SOC, \%

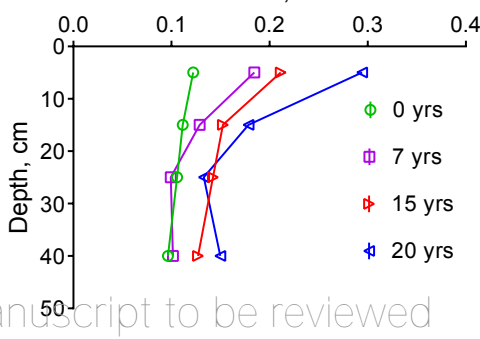

N, \%

$\mathrm{H}$

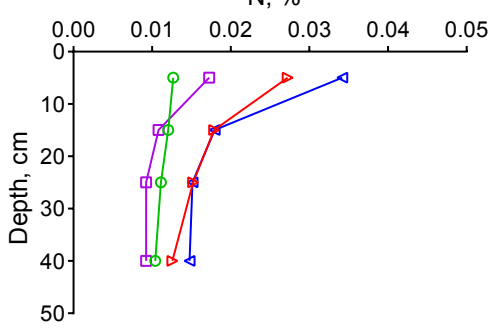

I

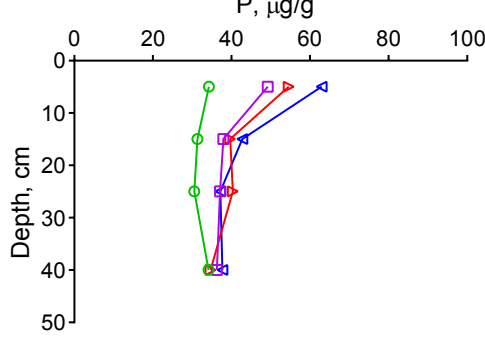

J

$\mathrm{P}_{\mathrm{av}}, \mu \mathrm{g} / \mathrm{g}$

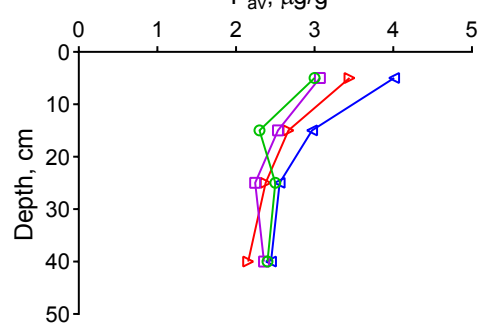

K

$\mathrm{K}, \mathrm{mg} / \mathrm{g}$

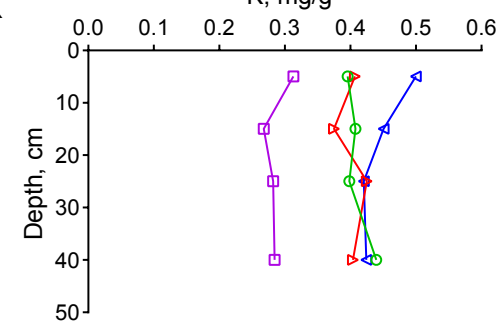

L

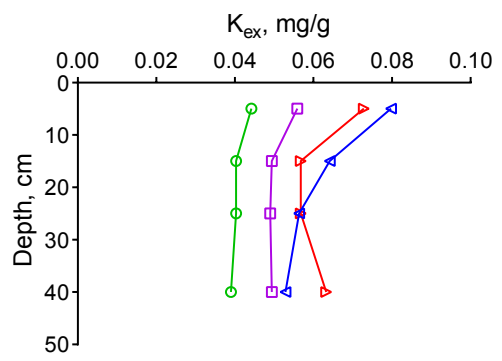


Figure 3 (on next page)

Dependence of soil $N(A)$, total $P(B)$, available $P(C)$, total $K(D)$ and extractable $K(E)$ on SOC concentrations all soil layers for grassland and plantations by age acrossand for the two study sites. 


\section{A PeerJ}

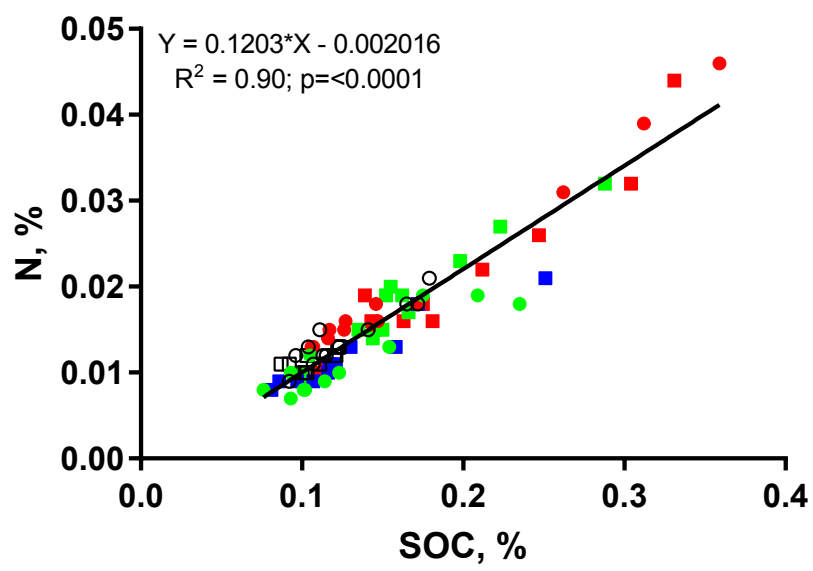

B

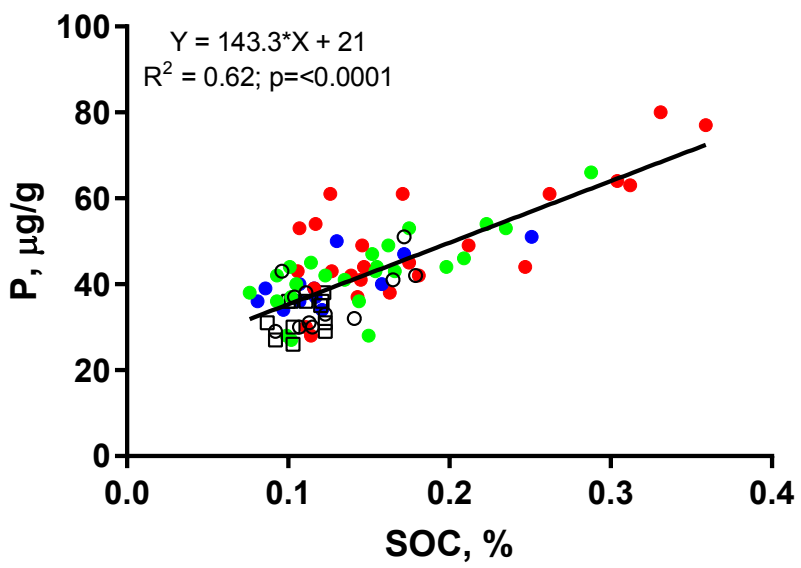

D

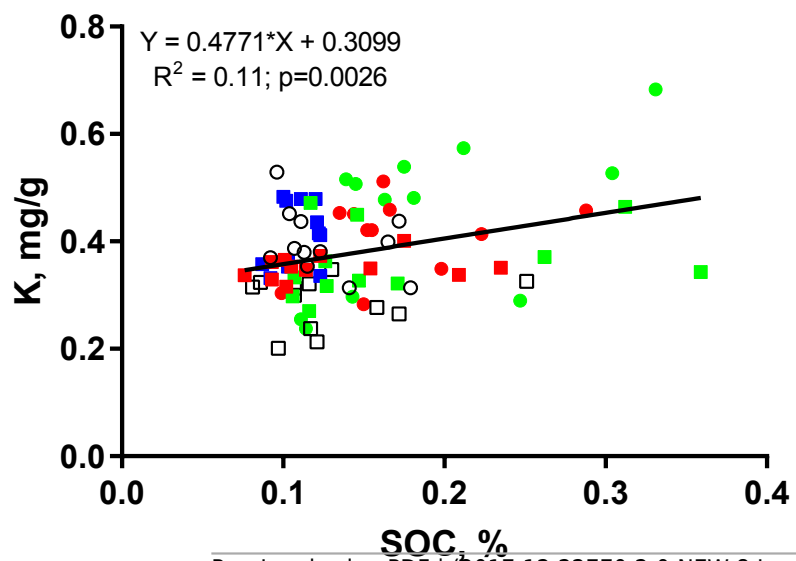

Peer) reviewing PDF |(2017:12:22770:2:0:NEW 8 Jun 2018)
- El Demokeya grassland

- El Demokeya 15 yrs

- El Demokeya 24 yrs

- El Hemaira grassland

- El Hemaira 7 yrs

- El Hemaira 15 yrs

- El Hemaira 20 yrs
C

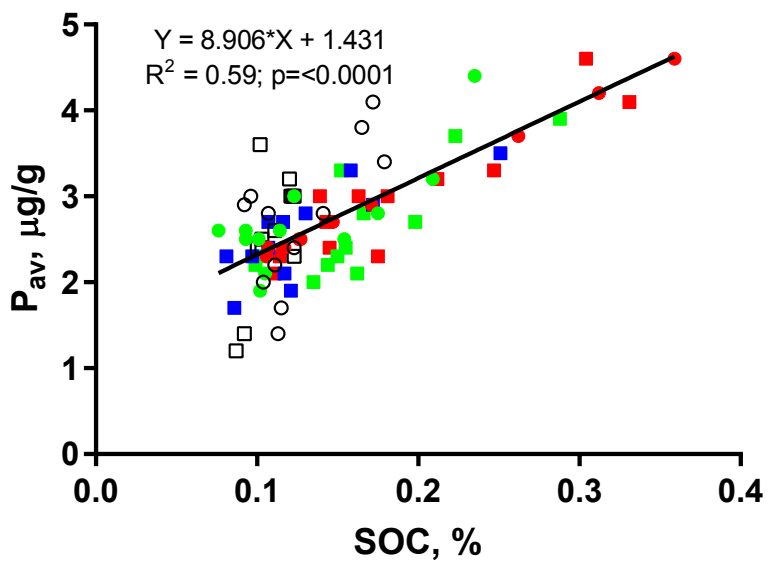

$E$

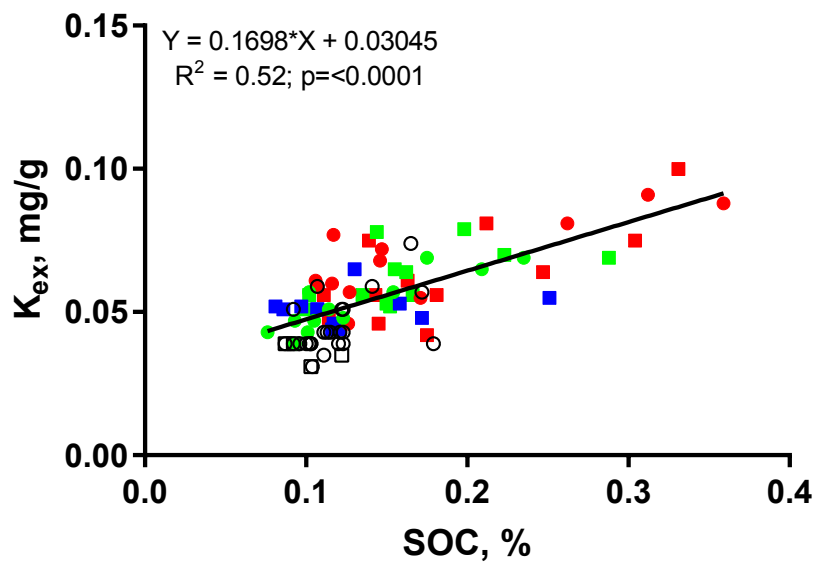


Figure 4 (on next page)

Relationship between soil $\delta{ }^{15} \mathrm{~N}(\%)$ and soil C:N ratios for grasslands and plantations by age for the two study sites across all plots and depths.

Dotted line is the linear regression fitted to the plantation data only $(Y=-0.452 * X+11.31$, $R^{2}=0.1926, p=0.0005$ ). 


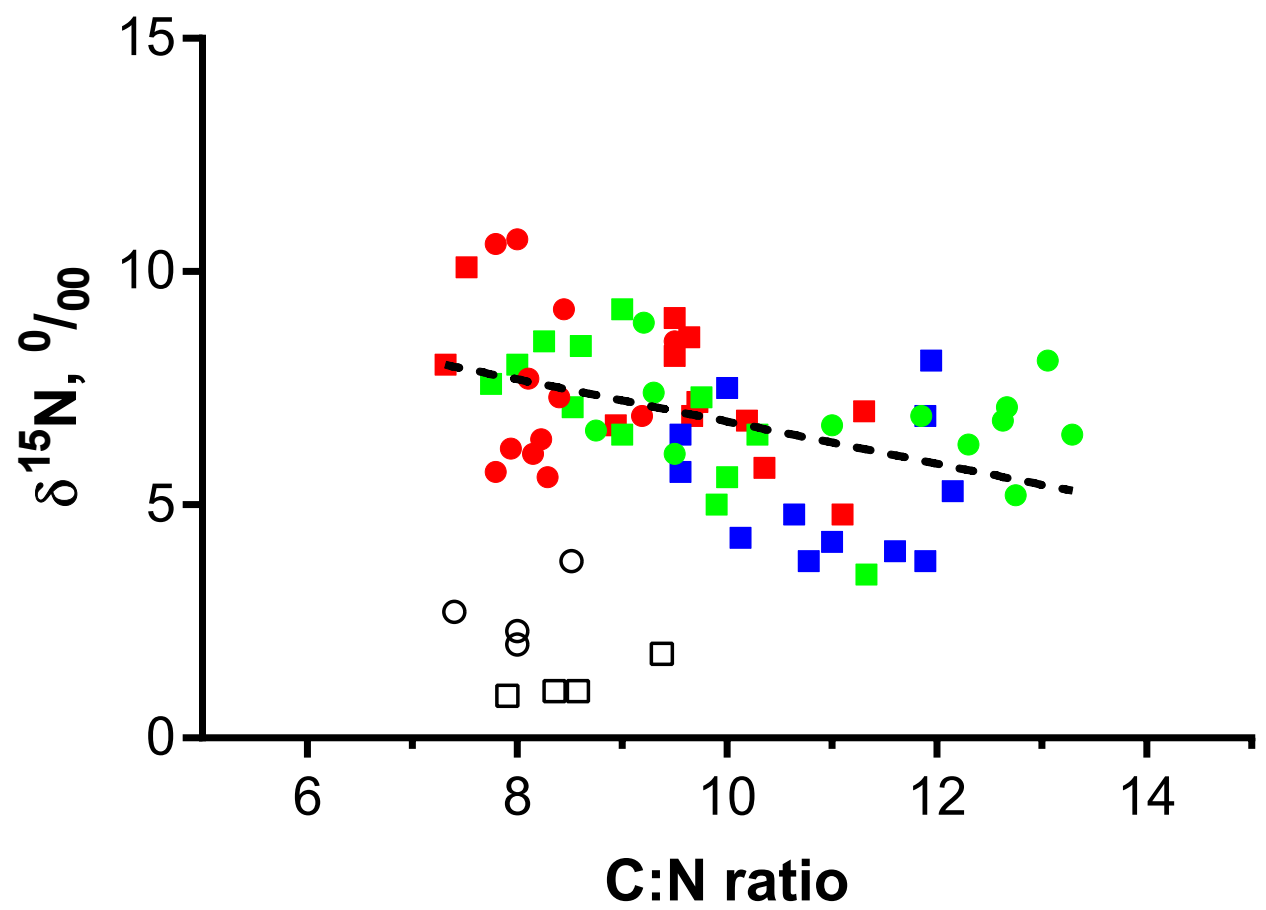

- El Demokeya grassland

- El Demokeya 15 yrs

- El Demokeya 24 yrs

- El Hemaira grassland

- El Hemaira 7 yrs

- El Hemaira 15 yrs

- El Hemaira 20 yrs 


\section{Table $\mathbf{1}$ (on next page)}

Pearson correlations between $\mathrm{SOC}$ and $\mathrm{N}$, total $\mathrm{P}$, available $\mathrm{P}$, total $\mathrm{K}$, extractable $\mathrm{K}$ concentrations by soil layer across all plots separately for El Demokeya $(n=9)$ and El Hemaira $(n=12)$ sites.

Significant $(\alpha=0.05)$ correlations are given in bold. 


\begin{tabular}{lllllll}
\hline Site & Layer, $\mathrm{cm}$ & $\mathrm{N}$ & $\mathrm{P}$ & $\mathrm{P}_{\mathrm{av}}$ & $\mathrm{K}$ & $\mathrm{K}_{\text {ex }}$ \\
\hline El Demokeya & $0-10$ & $\mathbf{0 . 9 4 2}$ & $\mathbf{0 . 9 1 5}$ & 0.634 & 0.006 & $\mathbf{0 . 7 4 9}$ \\
& $10-20$ & $\mathbf{0 . 6 7 5}$ & 0.600 & $\mathbf{0 . 8 1 7}$ & -0.323 & 0.637 \\
& $20-30$ & $\mathbf{0 . 6 5 2}$ & 0.442 & 0.144 & -0.064 & 0.366 \\
& $30-50$ & $\mathbf{0 . 7 2 9}$ & 0.182 & -0.302 & -0.307 & $\mathbf{0 . 7 5 7}$ \\
El Hemaira & $0-10$ & $\mathbf{0 . 9 5 0}$ & $\mathbf{0 . 8 6 9}$ & $\mathbf{0 . 8 4 8}$ & 0.566 & $\mathbf{0 . 7 6 2}$ \\
& $10-20$ & $\mathbf{0 . 8 2 7}$ & $\mathbf{0 . 6 9 9}$ & $\mathbf{0 . 6 5 7}$ & 0.558 & $\mathbf{0 . 8 6 2}$ \\
& $20-30$ & $\mathbf{0 . 9 0 6}$ & $\mathbf{0 . 7 3 2}$ & 0.434 & $\mathbf{0 . 7 3 2}$ & 0.529 \\
& $30-50$ & $\mathbf{0 . 9 3 6}$ & $\mathbf{0 . 6 6 3}$ & 0.170 & $\mathbf{0 . 5 7 6}$ & 0.365 \\
\hline
\end{tabular}




\section{Table 2 (on next page)}

Soil stocks ( $\mathrm{g} \mathrm{m}^{-2} ; 0-50 \mathrm{~cm}$ layer) of SOC, N, total P, available $\mathrm{P}$, total $\mathrm{K}$ and extractable $\mathrm{K}$ for grassland and plantations (under canopy) by age for the two study sites.

Values are mean values $(n=3)$ followed by standard deviation (in parentheses). Within each site, mean values sharing the same superscript are not significantly different from each other (Tukey's HSD, $\alpha<0.05$ ).

* SOC values from Abaker et al. (2016) ** grassland 


\begin{tabular}{lccccccc}
\hline Site & Age & \multicolumn{1}{c}{ SOC $^{*}$} & $\mathrm{~N}$ & $\mathrm{P}$ & $\mathrm{P}_{\mathrm{av}}$ & $\mathrm{K}$ & $\mathrm{K}_{\text {ex }}$ \\
\hline El Demokeya & $0^{* *}$ & $950(51)^{a}$ & $105(11)^{\mathrm{a}}$ & $28(3.1)^{\mathrm{a}}$ & $2.1(0.1)^{\mathrm{a}}$ & $315(33)^{\mathrm{a}}$ & $38.0(8.0)^{\mathrm{a}}$ \\
& 15 & $1024(143)^{a b}$ & $93(10)^{\mathrm{a}}$ & $35(1.5)^{\mathrm{ab}}$ & $2.2(0.2)^{\mathrm{a}}$ & $291(5)^{\mathrm{a}}$ & $43.0(4.5)^{\mathrm{a}}$ \\
& 24 & $1260(122)^{\mathrm{b}}$ & $153(15)^{\mathrm{b}}$ & $41(7.6)^{\mathrm{b}}$ & $2.2(0.1)^{\mathrm{a}}$ & $273(28)^{\mathrm{a}}$ & $51.5(2.1)^{\mathrm{b}}$ \\
& & & & & & & \\
El Hemaira & $0^{* *}$ & $867(59)^{a}$ & $92(1)^{\mathrm{a}}$ & $27(2.0)^{\mathrm{a}}$ & $2.1(0.6)^{\mathrm{a}}$ & $339(43)^{\mathrm{a}}$ & $33.0(0.6)^{\mathrm{a}}$ \\
& 7 & $982(190)^{a b}$ & $89(13)^{\mathrm{a}}$ & $32(1.2)^{\mathrm{a}}$ & $2.0(0.3)^{\mathrm{a}}$ & $230(40)^{\mathrm{a}}$ & $40.6(3.1)^{\mathrm{ab}}$ \\
& 15 & $1216(138)^{a b}$ & $136(27)^{\mathrm{ab}}$ & $33(6.4)^{\mathrm{a}}$ & $2.0(0.2)^{\mathrm{a}}$ & $323(60)^{\mathrm{a}}$ & $50.1(2.0)^{\mathrm{b}}$ \\
& 20 & $1422(240)^{\mathrm{b}}$ & $151(32)^{\mathrm{b}}$ & $34(6.4)^{\mathrm{a}}$ & $2.3(0.3)^{\mathrm{a}}$ & $349(119)^{\mathrm{a}}$ & $48.1(9.6)^{\mathrm{b}}$ \\
\hline
\end{tabular}




\section{Table 3(on next page)}

Soil $\mathrm{C}, \mathrm{N}$ and $\mathrm{P}$ stoichiometric ratios for the grassland and plantations by age and layer $(\mathrm{cm})$. Values are plot age mean values $(n=3)$.

Values within each site and soil layer sharing the same superscript letter or having no letter are not significantly different from each other (Tukey's HSD, $\alpha<0.05$ ).

* grassland 


\begin{tabular}{|c|c|c|c|c|c|c|c|c|c|c|c|c|c|}
\hline \multirow[t]{2}{*}{ Site } & \multirow{2}{*}{$\begin{array}{l}\text { Age } \\
\text { (yrs) }\end{array}$} & \multicolumn{4}{|c|}{$\mathrm{C}: \mathrm{N}$} & \multicolumn{4}{|c|}{$\mathrm{N}: \mathrm{P}$} & \multicolumn{4}{|c|}{$C: P$} \\
\hline & & $0-10$ & $10-20$ & $20-30$ & $30-50$ & $0-10$ & $10-20$ & $20-30$ & $30-50$ & $0-10$ & $10-20$ & $20-30$ & $30-50$ \\
\hline El Demokeya & 15 & 11.1 & 10.9 & 11.2 & 11.2 & $3.7^{\mathrm{a}}$ & 2.7 & 2.4 & 2.1 & 41.0 & 29.2 & 26.1 & 23.1 \\
\hline \multirow[t]{3}{*}{ El Hemaira } & $0^{*}$ & 9.6 & 9.2 & 9.5 & 9.3 & $3.8^{\mathrm{a}}$ & 3.9 & 3.7 & 3.1 & 36.2 & 35.6 & 35.1 & 28.2 \\
\hline & 7 & 10.5 & 11.9 & 10.7 & 11.1 & $3.5^{\mathrm{a}}$ & 2.9 & 2.5 & 2.5 & 37.4 & 34.1 & 26.8 & 28.0 \\
\hline & 15 & 8.7 & 8.7 & 9.5 & 10.3 & $5.0^{\mathrm{ab}}$ & 4.6 & 3.7 & 3.6 & 43.4 & 40.4 & 35.4 & 36.8 \\
\hline
\end{tabular}




\section{Table 4(on next page)}

Mean ( $\&$ standard deviation) N, $P$ and $K$ concentrations $\left(\mathrm{mg} \mathrm{g}^{-1}\right)$ and N:P ratio in acacia leaves $(n=3)$, above ground vegetation in the grassland $(n=2)$ and plantations $(n=5)$ at each of the two study sites.

* grassland 


\begin{tabular}{lclllll}
\hline Site & Age (yrs) & Sample & $\mathrm{N}$ & $\mathrm{P}$ & $\mathrm{K}$ & $\mathrm{N}: \mathrm{P}$ \\
\hline El Demokeya & $0^{*}$ & Grd. veg. & 12.1 & 2.7 & 23.5 & 4.6 \\
& 15 & Acacia leaves & $40.0(1.8)$ & $0.7(0.05)$ & $4.6(0.1)$ & 59.3 \\
& & Grd. veg. & $11.6(1.6)$ & $2.3(0.6)$ & $19.9(3.5)$ & 5.3 \\
& 24 & Acacia leaves & $39.4(1.7)$ & $0.7(0.04)$ & $4.2(0.6)$ & 59.2 \\
& & Grd. veg. & $13.0(1.6)$ & $1.8(0.3)$ & $16.6(5.8)$ & 7.6 \\
El Hemaira & \multirow{2}{*}{$0^{*}$} & Grd. veg. & 11.8 & 0.9 & 17.1 & 13.5 \\
& 7 & Acacia leaves & $38.4(2.9)$ & $0.5(0.0)$ & $5.2(1.3)$ & 70.3 \\
& \multirow{2}{*}{15} & Grd. veg. & $16.1(4.5)$ & $1.5(0.3)$ & $16.6(8.0)$ & 11.1 \\
& & Acacia leaves & $41.4(2.1)$ & $0.6(0.0)$ & $3.5(0.5)$ & 73.7 \\
& \multirow{2}{*}{20} & Grd. veg. & $11.6(3.7)$ & $1.8(0.6)$ & $20.3(4.6)$ & 6.9 \\
& & Acacia leaves & $40.0(5.3)$ & $0.9(0.4)$ & $4.4(0.8)$ & 52.6 \\
& & Grd. veg. & $19.2(5.3)$ & $3.9(0.7)$ & $30.7(8.3)$ & 4.9 \\
\hline
\end{tabular}




\section{Table 5 (on next page)}

$\delta{ }^{15} \mathrm{~N}$ values (\%) for acacia leaves $(n=3)$, aboveground vegetation ( $n=2$ for grassland, and $n=5$ for plantations) and soil $(n=3)$ by plantation age at the two study sites.

Values are mean values followed by standard deviation (in parentheses). Soil grassland value is for a single composite sample from one plot.

* grassland 


\begin{tabular}{|c|c|c|c|c|c|c|c|}
\hline \multirow[t]{2}{*}{ Site } & \multirow{2}{*}{$\begin{array}{l}\text { Age } \\
\text { (yrs) }\end{array}$} & \multirow{2}{*}{$\begin{array}{l}\text { Acacia } \\
\text { leaves }\end{array}$} & \multirow{2}{*}{$\begin{array}{l}\text { Ground } \\
\text { Veg. }\end{array}$} & \multicolumn{4}{|c|}{ Soil layer $(\mathrm{cm})$} \\
\hline & & & & $0-10$ & $10-20$ & $20-30$ & $30-50$ \\
\hline \multirow[t]{3}{*}{ El Demokeya } & $0^{*}$ & - & 2.9 & 3.8 & 2.7 & 2.3 & 2.0 \\
\hline & 15 & $6.5(1.5)$ & $3.2(1.1)$ & $7.9(1.1)$ & $6.9(0.2)$ & $6.8(0.6)$ & $5.9(0.7)$ \\
\hline & 24 & $7.0(1.5)$ & $3.8(1.5)$ & $10.2(0.9)$ & $7.7(0.8)$ & $6.4(0.8)$ & $6.0(0.4)$ \\
\hline \multirow[t]{4}{*}{ El Hemaira } & $0^{*}$ & - & 5.8 & 1.8 & 1.0 & 1.0 & 0.9 \\
\hline & 7 & $8.8(1.2)$ & $7.9(2.0)$ & $7.4(0.8)$ & $5.4(1.3)$ & $4.5(1.1)$ & $4.3(0.5)$ \\
\hline & 15 & $8.9(0.5)$ & $5.5(1.7)$ & $8.7(0.4)$ & $7.1(1.3)$ & $6.5(1.2)$ & $5.5(1.7)$ \\
\hline & 20 & $8.0(1.4)$ & $6.7(1.2)$ & $9.1(0.9)$ & $7.4(1.0)$ & $6.9(1.1)$ & $6.2(1.3)$ \\
\hline
\end{tabular}

